\title{
Universal screening at age 1-2 years as an adjunct to cascade testing for familial hypercholesterolaemia in the UK: a cost-utility analysis
}

Short title: Cost-effectiveness of universal screening for familial hypercholesterolaemia

Authors AJ McKay $\mathrm{PhD}^{1}$, H Hogan $\mathrm{PhD}^{2}$, SE Humphries $\mathrm{FRCP}^{3}$, D Marks $\mathrm{PhD}^{4}, \mathrm{KK}$ Ray FRCP5, A Miners $\mathrm{PhD}^{2}$

\section{Affiliations}

1. London School of Hygiene and Tropical Medicine, London, United Kingdom (MSc candidate 2016-17)

2. Department of Health Services Research and Policy, London School of Hygiene and Tropical Medicine, London, United Kingdom

3. Cardiovascular Genetics, Institute of Cardiovascular Science, University College London, London, United Kingdom

4. Department of Public Health, Environments and Society, London School of Hygiene and Tropical Medicine, London, United Kingdom

5. Department of Primary Care and Public Health, Imperial College London, London, United Kingdom

Corresponding author Ailsa McKay, ailsa.mckay08@imperial.ac.uk

Key words Hyperlipoproteinaemia type II, systematic population screening, costeffectiveness

Word count 3,148

Abstract word count 278

Tables 4

Figures 1

Supplementary files 9 


\section{Abstract}

Background The natural history of familial hypercholesterolaemia $(\mathrm{FH})$, benefit of early intervention, and under-diagnosis, present a case for screening. Cascade testing (CT) of relatives has been shown to be feasible, acceptable and cost-effective in the UK, but is dependent on a supply of index cases. Feasibility of universal screening (US) at age 1-2 years was recently demonstrated. We examined whether this would be a cost-effective adjunct to CT in the UK, given the current and plausible future undiagnosed $\mathrm{FH}$ prevalence.

Methods Seven cholesterol and/or mutation-based US \pm reverse cascade testing (RCT) alternatives were compared with no US in an incremental analysis with a UK NHS perspective. A decision model was used to estimate costs and outcomes for cohorts exposed to the US component of each strategy. RCT case ascertainment was modelled using recent UK CT data, and probabilistic Markov models estimated lifetime costs and health outcomes for the cohorts screened under each alternative. 1,000 Monte Carlo simulations were run for each model, and average outcomes reported. Further uncertainty was explored deterministically. Threshold analysis investigated the association between undiagnosed $\mathrm{FH}$ prevalence and cost-effectiveness.

Findings A strategy involving cholesterol screening followed by diagnostic genetic testing and then RCT was the most cost-effective alternative modelled (incremental cost-effectiveness ratio (ICER) versus no screening £12,480/quality adjusted life year (QALY); probability of cost-effectiveness $96 \cdot 8 \%$ at $£ 20,000 / Q A L Y$ threshold). Costeffectiveness was robust to the deterministic sensitivity analyses, and threshold analysis suggested that sequential cholesterol screening-genetic testing plus RCT would remain cost-effective even if ongoing case ascertainment reached theoretical maximum levels.

Interpretation These findings support implementation of universal cholesterol screening followed by diagnostic genetic testing and $\mathrm{RCT}$ for $\mathrm{FH}$, under a UK conventional willingness-to-pay threshold.

\section{Funding None}




\section{Research in context}

\section{Evidence before this study}

In the UK, fewer than $15 \%$ of those with familial hypercholesterolaemia $(\mathrm{FH})$ have been diagnosed. Cascade testing of relatives has been recommended in the UK for several years, and has been shown to be feasible, acceptable and cost-effective, but requires a supply of index cases. Index cases could potentially be supplied by universal screening, which has recently been shown to be feasible at age 1-2 years.

\section{Added value of this study}

This study suggests that universal screening of the UK population at 1-2 years would be cost-effective. Of several screening alternatives modelled, cholesterol screening followed by diagnostic genetic testing plus reverse cascade testing was found to be the most cost-effective. Although a successful screening programme would reduce its own cost-effectiveness by reducing undiagnosed disease prevalence and therefore pre-test probability of disease, our findings indicate that universal screening would remain cost-effective even if it continually achieved maximum plausible case ascertainment.

\section{Implications of all the available evidence}

Taken together with demonstrated feasibility and indications of acceptability of universal screening, these findings support implementation of universal screening for $\mathrm{FH}$ at 1-2 years, in the UK. 


\section{Introduction}

Familial hypercholesterolaemia $(\mathrm{FH})$ is characterised by elevated low-density lipoprotein cholesterol (LDL-C) from birth, and is associated with elevated risk of coronary heart disease (CHD). ${ }^{1}$ A recent general population study described an odds of $\mathrm{CHD}$ for the average untreated $\mathrm{FH}$ phenotype around 13-fold higher than that of the non-FH phenotype. ${ }^{2}$ This relative risk is age-dependent, being higher in younger agegroups. ${ }^{3}$ Mortality at $<30$ years is typical of untreated homozygous disease, ${ }^{4}$ whereas the heterozygous genotype confers approximately $50 \%$ risk of $\mathrm{CHD}$ by 50 years among males, and $30 \%$ risk of CHD by 60 years in females. ${ }^{5,6}$ Recent prevalence estimates for heterozygous disease range from 1/250-1/200 (1/300,000-1/160,000 for homozygous disease). ${ }^{7,8}$ It is therefore anticipated that there are approximately 187,500-328,200 people with FH in the UK, but estimates suggest fewer than 15\% have been diagnosed..$^{9,10}$ Those undiagnosed represent a substantial reservoir of potentially modifiable cardiovascular disease (CVD) risk.

The aim of $\mathrm{FH}$ treatment is LDL-C reduction via lifestyle modification and lipid modifying therapy (LMT). Limited trial data has constrained treatment at young ages, but recent studies support early intervention. Legacy effects from statin trials indicate greater treatment benefit with earlier initiation. ${ }^{11}$ Young people with treated $\mathrm{FH}$ exhibit longer event-free survival than their affected parents, who experienced relative delay to statin therapy; ${ }^{12}$ and recent trials have demonstrated statin impact on carotid intimamedia thickness (a measure of carotid atherosclerosis) in childhood, with younger age of therapy initiation associated with more limited atherosclerotic progression. ${ }^{13}$ Although only short term efficacy and safety data are available,${ }^{14,15}$ the data supporting early treatment, the premature, often unheralded consequences of $\mathrm{FH}$, and widespread under-diagnosis, ${ }^{9}$ have led to recommendations for screening and early treatment. $^{9,16}$

Since 2008, the UK National Institute for Health and Care Excellence (NICE) has recommended cascade testing (CT, of first-, second- and third- degree relatives) for $\mathrm{FH},{ }^{16}$ and this has been shown to be feasible, acceptable and cost-effective. ${ }^{17,18}$ There has been limited roll-out of CT in England, as local teams have not commissioned the relevant services, but it has been relatively successful in other parts of the UK. ${ }^{19}$ As CT depends on index case supply, there is interest in screening to identify index cases. Both adult and childhood systematic population screening (or 'universal screening'; US) for FH remain under review by the UK National Screening Committee (NSC). Recent NSC external review has considered that the NHS Health Check may 
represent an adulthood $\mathrm{FH}$ screening mechanism, ${ }^{20}$ but we are unaware of data supporting this. Moreover, the reach of Health Checks is restricted and increasingly so under the current contraction of UK local public health budgets. ${ }^{21,22}$ Feasibility of otherwise screening in adulthood has not been demonstrated, and no model for adult screening has been described. There are also theoretical reasons to favour screening in childhood. The false positive and false negative $\mathrm{FH}$ case detection rates for given cholesterol thresholds appear to be most favourable at young ages, ${ }^{23}$ and screening at younger ages enables intervention at an early stage of atherosclerosis development, when maximum benefit can still be obtained via lifestyle adaptations and LMT. The feasibility of US at age 1-2 years has recently been demonstrated, ${ }^{24}$ but costeffectiveness is unclear.

We therefore aimed to determine whether US for $\mathrm{FH}$ at 1-2 years could be a costeffective adjunct to CT in the UK. Our main objective was to compare the costeffectiveness of cholesterol and/or mutation-based US \pm reverse cascade testing (RCT; where feasible) alternatives (detailed in Box 1), at current undiagnosed FH prevalence. We also examined whether there would be a point at which US would lose cost-effectiveness (due to falling FH prevalence as a result of screening and CT).

\section{Box 1: Universal screening alternatives considered}

1. No universal screening (allows for any ongoing cluster testing)

2. Cholesterol screening

3. Sequential genetic testing-cholesterol screening (i.e. genetic testing followed by cholesterol screening among mutation-positive individuals)

4. Sequential cholesterol screening-genetic testing (i.e. cholesterol screening followed by genetic testing among cholesterol-positive individuals)

5. Parallel cholesterol screening-genetic testing (i.e. cholesterol screening coincident with genetic testing)

6-8. Comparators 3-5, respectively, plus reverse cascade testing

NB. It was assumed all strategies would include assessment against clinical diagnostic criteria, hence only comparator two would result in some individuals being partially tested against standard UK diagnostic criteria and at risk of false positive results 


\section{Methods}

\section{Comparators, approach and perspective}

The alternatives described in Box 1 were compared (with reference to heterozygous FH only) from a UK NHS healthcare perspective. Methods were aligned with the NICE reference case so far as possible, ${ }^{25}$ in an incremental analysis that estimated lifetime (to a maximum of 100 years) costs and health outcomes (discounted at $3.5 \%$ per annum) for cohorts screened under each alternative. Where possible, modelling was based on UK data, and UK diagnostic criteria and treatment pathways. In the base case, definition of $\mathrm{FH}$ (for treatment purposes) was therefore a Simon Broome diagnosis plus hypercholesterolaemia (defined as total cholesterol exceeding the general population $95^{\text {th }}$ percentile). ${ }^{26,27}$ All (and only) mutation-positive individuals were considered as index individuals for RCT

The model had three main components:

1. A decision tree estimated outcomes for cohorts of 10,000 1-2 year olds exposed to the US component of each alternative

2. Local CT data were used to estimate RCT case ascertainment, given the number of mutation-positive individuals identified in US, and

3. Markov models estimated lifetime costs and health outcomes for the cohorts screened under each alternative, in view of the number of diagnoses made

Data for parameter estimation were obtained from a systematic review (published 2000), ${ }^{26}$ updated with a systematic literature search (detailed in Supplementary File 1) and data from a recent economic evaluation and the Welsh FH CT programme. ${ }^{17,28}$ As relevant data were sparse, no formal syntheses were undertaken and model parameters were estimated conservatively.

\section{Model structure and inputs}

The decision tree used to model US (Figure 1a) reflects simplified versions of the screening pathway used in the recent UK study that demonstrated US feasibility. ${ }^{24}$ The associated probabilities (Table 1) were combined to derive outcomes for each screening cohort (Supplementary File 2). We assumed there was no delay between US case-identification and RCT, and based on local data and an expectation that a US programme would facilitate improved $\mathrm{CT},{ }^{24,29}$ estimated base case RCT yield was two mutation-positive individuals per mutation-positive index individual. That is, where RCT was part of the screening alternative it was assumed two mutation-positive individuals would be identified via RCT for every mutation-positive individual identified in US. It 
was assumed the age-distribution of those identified by RCT would be as observed in the Welsh CT programme, ${ }^{17,28}$ and that $70 \%$ of RCT-identified mutation-positive relatives would meet the base case $\mathrm{FH}$ definition. ${ }^{30-32}$ For purposes of costing RCT (see below), probability of mutation detection among relatives was assumed to be Mendelian.

Separate Markov models estimated outcomes for cohorts of 1,000 diagnosed or undiagnosed individuals, starting from age two years, five years, and each subsequent five-year interval to 85 years. The modelling approach followed that used in the economic evaluation for NICE CG181, and a recent CT analysis, and is described fully in Supplementary File 3. ${ }^{17,33}$ Briefly, baseline CVD risks drew on the QRISK2 model, ${ }^{34}$ and the modelled health states included all constituent diagnoses of the QRISK outcome (see Figure 1b). Where QRISK2 was not validated for age-groups of interest, CVD risks were estimated using age-related CVD relative risks calculated from published data. ${ }^{35}$ The relative $\mathrm{CHD}$ death risks described for the pre-treatment era Simon Broome cohort were applied to the angina, MI and CHD death risks. ${ }^{3}$ Individuals progressed to post-CVD states in the cycle following development of non-fatal CVD, unless a further event or death occurred immediately. Secondary event risks obtained from NICE CG181 (with some adjustments - see Supplementary File 3) were applied without adjustment for $\mathrm{FH},{ }^{33}$ but the models did not allow for impact of multiple previous events. Non-CVD mortality was estimated from 2015 England and Wales Office for National Statistics mortality and mid-year population figures, ${ }^{36,37}$ and it was assumed that CVD and mortality risks for the youngest age-group (not specifically reported), were zero. Modelled treatment was based on national guidance and local audit and registry data, and was modelled until age 60 years (details in Supplementary File 4). ${ }^{10,16,38}$ Welsh FH audit age-band-specific pre-treatment LDL-C levels (concordant with national paediatric register data) were applied, ${ }^{17}$ and $37 \%$ treatment-related LDL$\mathrm{C}$ reduction modelled in the base case (as observed in the UK 2010 national $\mathrm{FH}$ audit, ${ }^{10}$ cf. $35 \%$ in paediatric register). ${ }^{38}$ Resultant expected treatment-related absolute LDL-C reductions were transformed to CVD relative risk reductions using the Cholesterol Treatment Trialists' (CTT) Collaboration-reported per mM values for nonfatal MI, ischaemic stroke, and CHD death (applied to angina and MI, TIA and stroke, and $\mathrm{CHD}$ death, risks, respectively). ${ }^{39}$ The CTT values were assumed applicable to both primary and secondary events.

Cycle health state outcomes were weighted with the utilities described in CG181, ${ }^{33}$ and costs and effects were discounted, enabling calculation of discounted quality-adjusted 
life year (QALY) and cost outcomes for each model. Models assumed no FH- or LMTassociated disutility, as per previous observation, ${ }^{40,41}$ and assumption that treatmentrelated disutility would prompt treatment modification, averting its persistence. To determine overall Markov model outcomes for each alternative, the outcomes from each model were combined according to the age-distribution and diagnosed/undiagnosed status of the individuals identified by US and RCT in at least one of the screening scenarios, for each alternative.

\section{Resource use and costs}

Costs were calculated in 2017 GBP. Modelled costs were current where possible, otherwise inflated to 2017 values, and assumed to remain constant (subject to discounting) over the model duration. Table 2 summarises the costs applied. Total US costs were estimated for each cohort by multiplying individual costs* probability of being incurred under the relevant strategy ${ }^{\star} 10,000$. CT costs per index individual were estimated as the costs of index individual consultation, plus screening costs for identified relatives (based on CG71 CT recommendations and associated costing template) $)^{*}$ the inverse of the probability of a relative being affected. Patient monitoring costs were applied only when patients were receiving LMT, except in cases of LMTnaïve individuals $<18$ years. At all ages, annual monitoring included blood sampling, lipid profile testing, and medical review (secondary care review at $<18$ years; 80:20 secondary:primary care split at $\geq 18$ years). ${ }^{10,29}$ Creatine kinase and $2 x$ liver function tests were costed for the first treatment year, plus an additional secondary care review if this was not the screening year.

\section{Management of uncertainty and calculations}

To include parameter uncertainty, Markov models were built probabilistically, with beta distributions applied for transition probabilities and utilities, log-normal distributions for the CVD relative risks associated with $\mathrm{FH}$ and $\mathrm{LDL}-\mathrm{C}$ reduction, and normal distribution for the pre-treatment LDL-C estimates (details in Supplementary File 5). 1,000 Monte Carlo simulations were run for each model. Uncertainty was further explored in a series of one-way DSAs, as outlined in Table 3, and the impact of including treatment costs for false positives identified in the cholesterol-only screening alternative (assuming treatment as per true positives, with estimated survival based on current standard life tables) ${ }^{42}$ was also considered.

In all analyses, ICERs were calculated for each alternative versus the next lowest cost. Dominated comparators were excluded and the remaining alternatives compared to 
the remaining next lowest cost, repeated as necessary. Cost-effectiveness was assessed using the $£ 20,000-£ 30,000$ NICE willingness-to-pay threshold, ${ }^{25}$ and costeffectiveness acceptability curves were plotted. Threshold analysis estimated the undiagnosed $\mathrm{FH}$ prevalences at which the ICER for the most cost-effective screening strategy crossed $£ 20,000 / Q A L Y$ and $£ 30,000 /$ QALY willingness-to-pay thresholds, under otherwise base case conditions \pm off-patent LMT costs (see Table 3 ). Scenarios in which CT yields were $2.4,6.1$ and 8.6 cases/index, and undiagnosed $\mathrm{FH}$ prevalences were 67,33 and $24 \%$, respectively, were also considered, as theoretical analyses indicate that such undiagnosed prevalences could not be reached with these CT yields. ${ }^{43}$ Analyses were carried out using MS Excel v14.7.7. 


\section{Results}

The sequential cholesterol screening-genetic testing plus RCT strategy was the most cost-effective in all analyses, and no scenario identified an additional strategy that could be cost-effectively provided. The number of $\mathrm{FH}$ cases identified under each screening strategy, costs per diagnosis, average QALYs gained, overall costs, and associated ICERs, are displayed in Table 4 (DSA estimates in Supplementary Files 6 and 7 ). Diagnosis rates ranged from $11 \cdot 4 / 10,000$ screened (sequential genetic testingcholesterol screening) to $25 \cdot 4 / 10,000$ (parallel cholesterol screening-genetic testing) without RCT, and $31 \cdot 1 / 10,000$ to $45 \cdot 1 / 10,000$ (same US strategies) with RCT. Costs per US diagnosis ranged from $£ 11,788$ (cholesterol-only screening) to $£ 217,036$ (sequential genetic-cholesterol screening). Cost per RCT diagnosis was $£ 1,110$. The lowest overall cost per diagnosis $(£ 8,886)$ was observed for the sequential cholesterol screening-genetic testing plus RCT strategy, which also achieved the second highest number of diagnoses $(39 \cdot 8 / 10,000)$. The ICER for this strategy versus no screening (£12,480/QALY) dominated all others except the parallel cholesterol-genetic US plus RCT scenario (ICER for direct comparison $=£ 399,581 / Q A L Y$ ).

As expected, ICERs were sensitive to RCT success, ranging from £6,269$£ 6,729 /$ QALY to $£ 18,253 /$ QALY across the RCT yields tested. Discounting at $1.5 \%$, and $50 \%$ treatment-related LDL-C reduction, were associated with relatively low ICERs (£5,489/QALY and $£ 7,733 / Q A L Y$, respectively). Only discounting at 5\% produced an ICER >£20,000/QALY (£20,849/QALY). Cost-effectiveness acceptability curves for the sequential cholesterol screening-genetic testing US plus RCT versus no screening comparison are displayed for several scenarios in Supplementary File 8. For the base case, probability of cost-effectiveness was $96.8 \%$ at a willingness-to-pay threshold of $£ 20,000 / \mathrm{QL} Y(100 \%$ at $£ 30,000 / \mathrm{QLL} Y)$.

Threshold analysis suggested US would be cost-effective at a $£ 20,000 / Q A L Y$ threshold until undiagnosed prevalence reached $<48 \% \quad(<30 \%$ for $£ 30,000 /$ QALY threshold). Corresponding prevalences were $<43 \%$ and $<28 \%$ with off-patent LMT costs. ICERs for the scenarios in which undiagnosed prevalences of $67 \%, 33 \%$ and $24 \%$, and respective CT yields of $2.4,6 \cdot 1$ and 8.6 cases per index, were modelled, were $£ 13,692 / Q A L Y, £ 14,630 / Q A L Y$ and $£ 15,680-£ 16,146 / Q A L Y$, respectively (£11,745/QALY, $£ 12,851 /$ QALY and $£ 13,653-14,115 /$ QALY with off-patent LMT costs). 


\section{Discussion}

\section{Summary of findings}

This study aimed to assess which of seven potential FH US strategies would be most cost-effective for the UK context, whether any would be cost-effective as per conventional NICE definition, and whether US could reduce undiagnosed FH prevalence to levels at which it would lose cost-effectiveness. Sequential cholesterol screening-genetic testing plus RCT was the most cost-effective alternative modelled, and cost-effectiveness was robust to DSAs and to reductions in undiagnosed prevalence that US could theoretically achieve. ${ }^{43}$ The modelled approach - with screening incorporated into routine child healthcare appointments - is efficient in terms of minimising user inconvenience, limiting additional healthcare costs, and potentially promoting screening engagement. As cholesterol results can be obtained by a pointof-care testing method, individuals with cholesterol levels below the threshold that would trigger genetic testing could be immediately reassured. While a mutation is only detected in a proportion of those with LDL-C above the threshold, a mutation confirms the diagnosis for these individuals, and unequivocal DNA-based diagnostic testing of relatives (so-called reverse cascade testing) can be undertaken. The clinical value of the approach is achieved by provision of LMT at a relatively young age, before high LDL-C burden has resulted in premature atherosclerosis and a CHD event.

\section{Comparison with existing literature}

Among 10,000 children eligible for US, the sequential cholesterol screening-genetic testing plus RCT strategy we found to be most cost-effective identified fewer children with hypercholesterolaemia plus an $\mathrm{FH}$ mutation $(\mathrm{n}=10.98)$ than reported per 10,095 children from the recent US feasibility study ( $n=21$ such cases identified). ${ }^{24}$ This may be explained by the fact that we accounted for non-attendance and non-participation, required hypercholesterolaemia on two rather than one tests (i.e. accounted for biological and analytical cholesterol variability), and used a slightly more restrictive definition of hypercholesterolaemia. Chance may also be relevant as the numbers are small. Reported costs per diagnosis were lower $(\$ 2,900$ and $£ 3,500)$ in recent studies than in our study, but this discrepancy is expected as in addition to the test costs \pm limited consultation time they considered, we allowed for more screening consultation time (as recommended by local clinicians familiar with $\mathrm{FH}$ testing), administrative costs, and initial specialist review. ${ }^{24,44}$ We did not find further recent estimates of diagnosis costs or US cost-effectiveness in children, but a 2002 HTA estimated both for US at 16 years. ${ }^{26}$ Comparability is limited by inflation and methodological differences. Nonetheless, reported costs per diagnosis from the 2002 study were 
$£ 9,754$ where clinically confirmed and $£ 72,140$ with genetic confirmation, ${ }^{26}$ and the corresponding costs per life year gained, (with discounting at $3 \%$ ), £7,244 and $£ 33,882 .{ }^{45}$ Given the interim reductions in genetic screening costs, these values probably support that those reported here are feasible.

The ICER of $£ 12,480 /$ QALY for sequential cholesterol screening-genetic testing plus RCT is as expected higher than that recently estimated for CT from known cases $\left(\right.$ ICER $=£ 5,806 /$ QALY). ${ }^{17,18}$ Although several parameters were modelled similarly in both analyses, the CT analysis did not model identification of index cases, ${ }^{17,18}$ which depends on testing with a much lower pre-test probability of disease, and is therefore associated with higher screening costs per diagnosis. As US enables $\mathrm{FH}$ diagnosis at a relatively young age, the differential latencies to treatment and impact on the natural history of the disease will also contribute to the CT versus US cost-effectiveness differences.

\section{Strengths and limitations}

This study appears to be the first to consider the cost-effectiveness of universal screening for $\mathrm{FH}$ at 1-2 years. The study compared the multiple screening options previously noted of interest, ${ }^{46}$ and recent local data were available to estimate several parameters.

The persistent uncertainty around the sensitivity and specificity of different cholesterol theresholds, ${ }^{47}$ although considered in DSA, is an important limitation of all work in this area. Additional limitations in parameter estimation included the required extrapolation of treatment efficacy data from non-FH populations beyond the duration of LMT trials, and beyond the intermediate outcomes of paediatric trials, and extrapolation of the CTT relative risk reduction estimates beyond primary events. Secondary CVD event risk estimates were limited by the time lapsed since their description and lack of adjustment for $\mathrm{FH}$. FH-specific utility data are few, and those applied (from non-FH populations) were drawn from studies that utilised a range of choice-based preference elicitation methods and samples (including non-UK-based samples). The model structure necessarily followed a simplified version of treatment pathways and did not include additional potential inputs such as dietetics and management of statinattributable diabetes, which appears in any case to be low in $\mathrm{FH}$ patients. ${ }^{48,49}$ The models also assumed no pre-existing CVD, which will not always be the case. ${ }^{50}$ Additional methodological limitations included the one-way modelling of uncertainties in DSA, when some could theoretically be realised in combination, and the 
'memoryless' characteristic of Markov models which constrained modelling of accumulating CVD burden.

\section{Implications for research and practice}

2016 NSC review recommended against US for FH. Lack of demonstrated costeffectiveness was a concern, but also practical feasibility, acceptability, and lack of evidence that US would reduce morbidity and mortality. ${ }^{51}$ Feasibility of direct demonstration of impact on morbidity and mortality has been questioned, as the ethical and time demands of clinical endpoint trials are likely unachievable. However, the feasibility of US has now been demonstrated, in a study that also indicated acceptability among parents, ${ }^{24}$ and other studies have similarly found that participants generally consider such screening beneficial. ${ }^{40,52-54}$ Together with our findings, which would conventionally (i.e. under the standard NICE threshold) support implementation of US, these studies support reconsideration of US. Cholesterol thresholds of alternative sensitivity/specificity (which may impact on US acceptability) could be considered in future analyses, when test performance at these thresholds has been described.

\section{Conclusions}

A sequential cholesterol screening-genetic testing plus RCT approach would be the most cost-effective FH US strategy for the UK. Although a successful screening programme would reduce undiagnosed $\mathrm{FH}$ prevalence and therefore screening costeffectiveness, sequential cholesterol screening-genetic testing plus RCT would remain cost-effective even if it continually achieved maximum plausible case ascertainment. 


\section{Acknowledgments}

We are grateful to Elizabeth Watson (Bristol Genetics Laboratory, Bristol, UK) for information regarding genetic testing costs, and to Kate Haralambos (Cardiff University, Cardiff, UK) for access to unpublished data from the Welsh familial hypercholesterolaemia screening programme.

\section{Ethics statement}

As this study was a secondary analysis of published data, formal ethical approval was not required.

\section{Contributorship}

AJM and AM designed the study. AJM carried out the analyses and wrote the first draft of the manuscript. All authors provided input and approved the final version for submission.

\section{Funding None}

SEH acknowledges support from the British Heart Foundation (BHF) (BHF PG08/008) and the NIHR UCLH BRC.

\section{Declaration of interests}

AJM, HH, DM and AM report no competing interests. SEH is the Medical Director and minority shareholder of a UCL spin-out company called StoreGene, which uses a 20 SNP genetic test, in combination with the classical risk factor profile, for estimating an individual's future risk of CVD, and which offers genetic testing for $\mathrm{FH}$ through an accredited diagnostic laboratory. SEH is a consultant for Color Genomics which offers genetic tests for $\mathrm{FH}$ in the US, and reports grants from the British Heart Foundation and International Atherosclerosis Society-Pfizer, outside the submitted work. SEH was one of the topic experts for the 2017 NICE FH guideline update of the $2008 \mathrm{FH}$ guideline CG71. KKR reports grants from Sanofi, Regeneron, Amgen, Pfizer and MSD, outside the submitted work. KKR reports personal fees from Sanofi, Amgen, Regeneron, Pfizer, Kowa, Algorithm, IONIS, Esperion, Medicines Company, Novo Nordisk, Takeda, Boehringer Ingelheim, Resverlogix, Abbvie, Cerenis, Cipla, Mylan, Janssen and Lilly, outside the submitted work. 


\section{References}

1. Brown MS, Goldstein JL. A receptor-mediated pathway for cholesterol homeostasis. Science 1986;232:34-47.

2. Benn M, Watts GF, Tybjaerg-Hansen A, Nordestgaard BG. Familial Hypercholesterolemia in the Danish General Population: Prevalence, Coronary Artery Disease, and Cholesterol-Lowering Medication. Journal Clin Endocrinol Metab 2012;97:3956-64.

3. Scientific Steering Committee on behalf of the Simon Broome Register Group. Risk of fatal coronary heart disease in familial hypercholesterolaemia. BMJ 1991;303:893-96.

4. Goldstein JL, Hobbs HH, Brown MS. Scriver CR, Beaudet AL, Sly WS, Valle D. Familial hypercholesterolemia. The metabolic and molecular bases of inherited disease, 8th ed. New York: McGraw-Hill, 2001. (pp. 2863-2913).

5. Slack J. Risks of ischaemic heart disease in familial hyperlipoproteinaemic states. Lancet 1969;294:1380-82.

6. Stone NJ, Levy RI, Fredrickson DS, et al. Coronary Artery Disease in 116 Kindred with Familial Type II Hyperlipoproteinemia. Circulation 1974;49:476-88.

7. Akioyamen LE, Genest J, Shan SD, et al. Estimating the prevalence of heterozygous familial hypercholesterolaemia: a systematic review and metaanalysis. BMJ Open 2017;7:e016461.

8. Santos RD, Gidding SS, Hegele RA, et al. Defining severe familial hypercholesterolaemia and the implications for clinical management: a consensus statement from the International Atherosclerosis Society Severe Familial Hypercholesterolemia Panel. Lancet Diabetes Endocrinol. 2017;4:850-61.

9. Nordestgaard BG, Chapman MJ, Humphries SE, et al. Familial hypercholesterolaemia is underdiagnosed and undertreated in the general population: guidance for clinicians to prevent coronary heart disease: consensus statement of the European Atherosclerosis Society. Eur Heart $J$ 2013;34:3478-90a.

10. Pedersen KMV, Humphries SE, Roughton M, Besford JS. National Clinical Audit of the Management of Familial Hypercholesterolaemia 2010: Full Report. Clinical Standards Department, Royal College of Physicians, December 2010. .

11. Ford I, Murray H, McCowan C, Packard CJ. Long-Term Safety and Efficacy of Lowering Low-Density Lipoprotein Cholesterol With Statin Therapy: 20-Year Follow-Up of West of Scotland Coronary Prevention Study. Circulation 2016;133:1073-80.

12. Braamskamp MJAM, Kastelein JJP, Kusters DM, Hutten BA, Wiegman A. Statin Initiation during Childhood in Patients with Familial Hypercholesterolemia Consequences for Cardiovascular Risk. J Am Coll Cardiol 2016;67:455-56.

13. Kusters DM, Avis HJ, de Groot E, et al. Ten-year follow-up after initiation of statin therapy in children with familial hypercholesterolemia. JAMA 2014;312:1055-7.

14. Vuorio A, Kuoppala J, Kovanen PT, et al. Statins for children with familial hypercholesterolemia. Cochrane Database Syst Rev 2017;7:CD006401.

15. Humphries SE, Cooper J, Dale P, Ramaswami U, FH Paediatric Register Steering Group. The UK Paediatric Familial Hypercholesterolaemia Register: Statin-related safety and 1-year growth data. J Clin Lipidol 2017;12:25-32.

16. National Institute for Health and Care Excellence. Familial hypercholesterolaemia: identification and management (CG71). NICE, 2008 (Last updated Novemeber 2017). 
17. Kerr M, Pears R, Miedzybrodzka Z, et al. Cost effectiveness of cascade testing for familial hypercholesterolaemia, based on data from familial hypercholesterolaemia services in the UK. Eur Heart J 2017;38:1832-39.

18. Nherera L, Marks D, Minhas R, Thorogood M, Humphries SE. Probabilistic costeffectiveness analysis of cascade screening for familial hypercholesterolaemia using alternative diagnostic and identification strategies. Heart 2011;97:1175-81.

19. Haralambos K, Ashfield-Watt $P$, Edwards R, et al. Five year experience of scoring criteria for familial hypercholesterolaemia $(\mathrm{FH})$ genetic testing in wales: Should the criteria be refined to include age? Atherosclerosis 2016;255:7-8.

20. Mackie A, Humphries SE, Neil HAW, on behalf of the Simon Broome Register Committee. Screening for familial hypercholesterolaemia in adults in the UK and the UK NSC screening criteria. June 2011. Available at: https://legacyscreening.phe.org.uk/familialhypercholesterolaemia-adult. Accessed: September 2017.

21. Robson J, Dostal I, Sheikh A, et al. The NHS Health Check in England: an evaluation of the first 4 years. BMJ Open 2016;6:e008840.

22. Chang K, Millett $C$, Soljak M, Majeed A. National coverage of the English NHS Health Check programme. Eur J Public Health 2014;24:cku165-033.

23. Wald DS, Bestwick JP, Wald NJ. Child-parent screening for familial hypercholesterolaemia: Screening strategy based on a meta-analysis. BMJ 2007;335:599-603.

24. Wald DS, Bestwick JP, Morris JK, Whyte K, Jenkins L, Wald NJ. Child-Parent Familial Hypercholesterolemia Screening in Primary Care. N Engl J Med 2016;375:1628-37.

25. National Institute for Health and Care Excellence. Guide to the methods of technology appraisal 2013. NICE, April 2013. Available at: https://www.nice.org.uk/process/pmg9/chapter/the-reference-case. Accessed: September 2017.

26. Marks D, Wonderling D, Thorogood M, Lambert H, Humphries SE, Neil HA. Screening for hypercholesterolaemia versus case finding for familial hypercholesterolaemia: a systematic review and cost effectiveness analysis. Health Technol Assess 2000; 4:1-123.

27. Fouchier SW, Hutten BA, Defesche JC. Current novel-gene-finding strategy for autosomal-dominant hypercholesterolaemia needs refinement. J Med Genet 2015;52:80-4.

28. Haralambos K, Wales Heart Research Institute, Cardiff. [Personal communication]

29. Hadfield SG, Horara S, Starr BJ, et al. Family tracing to identify patients with Familial Hypercholesterolaemia: the second Audit of the Department of Health Familial Hypercholesterolaemia Cascade Testing Project. Ann Clin Biochem 2009;46:24-32.

30. Damgaard D, Larsen ML, Nissen PH, et al. The relationship of molecular genetic to clinical diagnosis of familial hypercholesterolemia in a Danish population. Atherosclerosis 2005;180:155-60.

31. Humphries SE, Cranston T, Allen M, et al. Mutational analysis in UK patients with a clinical diagnosis of familial hypercholesterolaemia: relationship with plasma lipid traits, heart disease risk and utility in relative tracing. $J$ Mol Med 2006;84:203-14.

32. Umans-Eckenhausen MA, Defesche JC, Sijbrands EJ, Scheerder RL, Kastelein JJ. Review of first five years of screening for familial hypercholesterolaemia in the Netherlands. Lancet 2001;357:165-8.

33. National Clinical Guideline Centre. NICE clinical guideline CG181: Lipid modification: Cardiovascular risk assessment and the modification of blood 
lipids for the primary and secondary prevention of cardiovascular disease. Clinical Guideline Appendices. NICE, July 2014 (updated September 2016). Available at: https://www.nice.org.uk/guidance/cg181/evidence. Accessed: September 2017.

34. Hippisley-Cox J, Coupland C, Vinogradova Y, et al. Predicting cardiovascular risk in England and Wales: prospective derivation and validation of QRISK2. BMJ 2008;336:1475-82.

35. Bhatnagar $P$, Wickramasinghe $K$, Wilkins E, Townsend N. Trends in the epidemiology of cardiovascular disease in the UK. Heart 2016;102:19451952.

36. Office for National Statistics. Mortality statistics - underlying cause, sex and age [dataset]. Available at: https://www.nomisweb.co.uk/query/select/getdatasetbytheme.asp?opt=3\&the me=\&subgrp $=$. Accessed: September 2017.

37. Office for National Statistics. Population estimates - local authority based by five year age band [dataset]. Available at:

https://www.nomisweb.co.uk/query/select/getdatasetbytheme.asp?theme=32 Accessed: September 2017.

38. Ramaswami U, Cooper J, Humphries SE. The UK Paediatric Familial Hypercholesterolaemia Register: Preliminary data. Arch Dis Child 2017;102:255-60.

39. Cholesterol Treatment Trialists Collaboration. Efficacy and safety of more intensive lowering of LDL cholesterol: a meta-analysis of data from 170,000 participants in 26 randomised trials. Lancet 2010 376:1670-81.

40. de Jongh S, Kerckhoffs MC, Grootenhuis MA, Bakker HD, Heymans HS, Last BF. Quality of life, anxiety and concerns among statin-treated children with familial hypercholesterolaemia and their parents. Acta Pædiatr 2003;92:1096-101.

41. Retterstøl K, Stugaard M, Gørbitz C, Ose L. Results of intensive long-term treatment of familial hypercholesterolemia. Am J Cardiol 1996;78:1369-74.

42. Office for National Statistics. National life tables: England and Wales 2014-16 [dataset]. ONS, September 2017. Available at:

https://www.ons.gov.uk/peoplepopulationandcommunity/birthsdeathsandmarri ages/lifeexpectancies/datasets/nationallifetablesenglandandwalesreferenceta bles. Accessed: September 2017.

43. Morris JK, Wald DS, Wald NJ. The evaluation of cascade testing for familial hypercholesterolemia. Am J Med Genet A 2012;158a:78-84.

44. Wald DS, Kasturiratne A, Godoy A, et al. Child-Parent Screening for Familial Hypercholesterolemia. J Pediatr 2011;159:865-67.

45. Marks D, Wonderling D, Thorogood M, Lambert H, Humphries SE, Neil HA. Cost effectiveness analysis of different approaches of screening for familial hypercholesterolaemia. BMJ 2002;324:1303.

46. Ademi Z, Watts GF, Juniper A, Liew D. A systematic review of economic evaluations of the detection and treatment of familial hypercholesterolemia. Int J Cardiol 2013;167:2391-6.

47. Futema M, Cooper JA, Charakida M, et al. Screening for familial hypercholesterolaemia in childhood: Avon Longitudinal Study of Parents and Children (ALSPAC). Atherosclerosis 2017;260:47-55.

48. Besseling J, Kastelein JP, Defesche JC, Hutten BA, Hovingh GK. Association between familial hypercholesterolemia and prevalence of type 2 diabetes mellitus. JAMA 2015;313:1029-36.

49. Vuorio A, Strandberg TE, Schneider WJ, Kovanen PT. Statins and new-onset diabetes mellitus - a risk lacking in familial hypercholesterolaemia. J Intern Med 2016;279:358-61. 
50. Besseling J, Sjouke B, Kastelein JJP. Screening and treatment of familial hypercholesterolemia - Lessons from the past and opportunities for the future (based on the Anitschkow Lecture 2014). Atherosclerosis 2015;241:597-606.

51. Bazian Ltd for the UK National Screening Committee. Screening for familial hypercholesterolaemia in childhood: External review against programme appraisal criteria for the UK National Screening Committee (UK NSC). March 2015. Available at:

https://legacyscreening.phe.org.uk/familialhypercholesterolaemia-child. Accessed: September 2017.

52. Tonstad S. Familial hypercholesterolaemia: a pilot study of parents'and children's concerns. Acta Pædiatr 1996;85:1307-13.

53. Andersen LK, Jensen HK, Juul S, Faergeman O. Patients' attitudes toward detection of heterozygous familial hypercholesterolemia. Arch Intern Med 1997;157:553-60.

54. Meulenkamp TM, Tibben A, Mollema ED, et al. Predictive genetic testing for cardiovascular diseases: Impact on carrier children. Am J Med Genet A 2008;146A:3136-46. 


\section{Supplementary File 1: Systematic literature search - summary and example database search strategy}

Search terms were chosen with the aim of identifying information related to $\mathrm{FH}$ screening, diagnostics, treatment, and CVD and mortality outcomes, as well as previous economic evaluations of $\mathrm{FH}$ screening. Results were limited to those published since 1999, and to systematic reviews and meta-analyses, clinical trials, observational studies, other evaluations including economic evaluations, case series, registry data, guidelines, government publications and technical reports, published in English. Reference lists of included papers were also searched and further searches were carried out using the names of authors active in the field.

The Medline (via Pubmed), Embase (via Ovid), Cochrane Library, Health Management Information Consortium, NICE Evidence, Cost-Effectiveness Analysis Registry, Paediatric Economic Database Evaluation, and Centre for Reviews and Dissemination Database of Abstracts of Reviews of Effect, NHS Economic Evaluation Database, and Health Technology Assessment databases were searched on 08/08/2017.

\section{Keywords and additional terms used to generate database search strategies:}

\begin{tabular}{|c|c|c|}
\hline & Keyword & Additional terms \\
\hline Population & $\begin{array}{l}\text { Familial } \\
\text { hypercholesterolaemia }\end{array}$ & $\begin{array}{l}\text { Fredrickson hyperlipoproteinaemia, type Ila; } \\
\text { Hyperbetalipoproteinaemia; Hyperlipidaemia, } \\
\text { group A; Low-density-lipoprotein-type } \\
\text { hyperlipoproteinaemia }\end{array}$ \\
\hline Intervention & Mass screening[mesh] & Case-finding \\
\hline \multirow[t]{4}{*}{ Outcomes } & $\begin{array}{l}\text { Diagnostic tests, } \\
\text { routine[mesh] }\end{array}$ & $\begin{array}{l}\text { Symptom assessment[mesh]; Physical } \\
\text { examination[mesh]; Medical history } \\
\text { taking[mesh]; Clinical laboratory } \\
\text { techniques[mesh]; Diagnostic errors[mesh]; } \\
\text { Clinical decision-making[mesh] }\end{array}$ \\
\hline & $\begin{array}{l}\text { Genetic } \\
\text { techniques[mesh] }\end{array}$ & $\begin{array}{l}\text { Genotype[mesh]; Phenotype[mesh]; Genetic } \\
\text { heterogeneity[mesh]; Mutation[mesh]; } \\
\text { Polymorphism, genetic[mesh]; Genetic } \\
\text { Counseling[mesh] }\end{array}$ \\
\hline & CVD, mortality & $\begin{array}{l}\text { Myocardial ischaemia[mesh]; } \\
\text { cerebrovascular disorders[mesh]; peripheral } \\
\text { arterial disease[mesh]; vital statistics[mesh]; } \\
\text { death[mesh] }\end{array}$ \\
\hline & $\begin{array}{l}\text { Anticholesteremic } \\
\text { agents[mesh] }\end{array}$ & Treatment outcome[mesh] \\
\hline
\end{tabular}

\section{Example search strategy:}

Terms and filters used to search the Medline database via Pubmed

1. familial hypercholesterolaemia[Title/Abstract] OR familial hypercholesterolemia[Title/Abstract] 
2. cost and cost analysis[MeSH Terms] OR mass screening[MeSH Terms] OR diagnostic tests, routine[MeSH Terms] OR clinical chemistry tests[MeSH Terms] OR genetic testing[MeSH Terms] OR genotype[MeSH Terms] OR phenotype[MeSH Terms] OR genetic heterogeneity[MeSH Terms] OR mutation[MeSH Terms] OR polymorphism, genetic[MeSH Terms] OR genetic counseling[MeSH Terms] OR myocardial ischemia[MeSH Terms] OR cerebrovascular disorders[MeSH Terms] OR peripheral arterial disease[MeSH Terms] OR life expectancy[MeSH Terms] OR life tables[MeSH Terms] OR mortality[MeSH Terms] OR death[MeSH Terms] OR anticholesteremic agents[MeSH Terms] OR treatment outcome[MeSH Terms]

3. 1 AND 2

Filters applied:

1. Dates: 1999 - present

2. Article types: Clinical study, clinical trial (all phases), comparative study, consensus development conference, dataset, evaluation studies, government publications, guidelines, meta-analysis, multicenter study, observational study, practice guideline, pragmatic clinical trial, randomised controlled trial, systematic review, technical report, twin study, validation study 


\section{Supplementary File 2: Formulae applied in decision tree calculations}

Formulae presented only for outcomes not equal to zero

$\mathrm{FH}+$ : familial hypercholesterolaemia $(\mathrm{FH})$-positive, as per base case definition

$\mathrm{FH}-$ : $\mathrm{FH}$-negative, as per base case definition

$\mathrm{M}+\mathrm{FH}$ mutation-positive

$\mathrm{M}$-: FH mutation-negative

TC+: total cholesterol test results positive

TC-: total cholesterol test results negative

A1: first screening appointment attendance

$\mathrm{P} 1$ : screening participation at first appointment

A2: second screening appointment attendance

P2: screening participation at second appointment

\section{Branch 1: No screening}

\begin{tabular}{lll}
$\begin{array}{l}\text { Mutation } \\
\text { status }\end{array}$ & $\begin{array}{l}\text { Mutation status } \\
\text { determined }\end{array}$ & Formula \\
\hline False negatives & No & $p(F H+)^{*} p(M+\mid F H+)$ \\
\hline$M+$ & No & $p(F H+)^{*} p(M-\mid F H+)$ \\
\hline$M-$ & & \\
\hline True negatives & & $p(F H-)^{*} p(M+\mid F H-)$ \\
\hline$M+$ & No & $p(F H-)^{*} p(M-\mid F H-)$
\end{tabular}

Branch 2: cholesterol-only screening

\begin{tabular}{|c|c|c|}
\hline $\begin{array}{l}\text { Mutation } \\
\text { status }\end{array}$ & $\begin{array}{l}\text { Mutation status } \\
\text { determined }\end{array}$ & Formula \\
\hline \multicolumn{3}{|c|}{ True positives } \\
\hline$M_{+}$ & No & $\mathrm{p}(\mathrm{FH}+)^{*} \mathrm{p}(\mathrm{M}+\mid \mathrm{FH}+)^{*} \mathrm{p}(\mathrm{A} 1)^{*} \mathrm{p}(\mathrm{P} 1)^{*} \mathrm{p}(\mathrm{TC}+\mid \mathrm{FH}+)^{*} \mathrm{p}(\mathrm{A} 2)^{*} \mathrm{p}(\mathrm{P} 2)$ \\
\hline M- & No & $\mathrm{p}(\mathrm{FH}+)^{*} \mathrm{p}(\mathrm{M}-\mid \mathrm{FH}+)^{*} \mathrm{p}(\mathrm{A} 1)^{*} \mathrm{p}(\mathrm{P} 1)^{*} \mathrm{p}(\mathrm{TC}+\mid \mathrm{FH}+)^{*} \mathrm{p}(\mathrm{A} 2) * \mathrm{p}(\mathrm{P} 2)$ \\
\hline \multicolumn{3}{|r|}{ 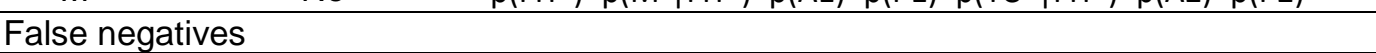 } \\
\hline $\mathrm{M}+$ & No & $\mathrm{p}(\mathrm{FH}+)^{*} \mathrm{p}(\mathrm{M}+\mid \mathrm{FH}+)-\mathrm{p}$ (true positive, $\mathrm{M}+$ status undetermined) \\
\hline M- & No & $\mathrm{p}(\mathrm{FH}+)^{*} \mathrm{p}(\mathrm{M}-\mid \mathrm{FH}+)-\mathrm{p}$ (true positive, $\mathrm{M}$ - status undetermined) \\
\hline \multicolumn{3}{|c|}{ True negatives } \\
\hline $\mathrm{M}+$ & No & $p(\mathrm{FH}-)^{*} \mathrm{p}(\mathrm{M}+\mid \mathrm{FH}-)-\mathrm{p}($ false positive, $\mathrm{M}+$ status undetermined $)$ \\
\hline M- & No & $\mathrm{p}(\mathrm{FH}-)^{*} \mathrm{p}(\mathrm{M}-\mid \mathrm{FH}-)-\mathrm{p}$ (false positive, $\mathrm{M}$ - status undetermined) \\
\hline \multicolumn{3}{|c|}{ False positives } \\
\hline $\mathrm{M}+$ & No & $p(F H-)^{*} p(M+\mid F H-)^{*} p(A 1)^{*} p(P 1)^{*} p(T C+\mid F H-)^{*} p(A 2)^{*} p(P 2)$ \\
\hline M- & No & $\mathrm{p}(\mathrm{FH}-)^{*} \mathrm{p}(\mathrm{M}-\mid \mathrm{FH}-)^{*} \mathrm{p}(\mathrm{A} 1)^{*} \mathrm{p}(\mathrm{P} 1)^{*} \mathrm{p}(\mathrm{TC}+\mid \mathrm{FH}-)^{*} \mathrm{p}(\mathrm{A} 2)^{*} \mathrm{p}(\mathrm{P} 2)$ \\
\hline
\end{tabular}

Branch 3: genetic-only screening

\begin{tabular}{lll}
$\begin{array}{l}\text { Mutation } \\
\text { status }\end{array}$ & $\begin{array}{l}\text { Mutation status } \\
\text { determined }\end{array}$ & Formula \\
\hline True positives & & \\
\hline \multicolumn{1}{c}{$\mathrm{M}_{+}$} & Yes & $\mathrm{p}(\mathrm{FH}+)^{*} \mathrm{p}(\mathrm{A} 1)^{*} \mathrm{p}(\mathrm{P} 1)^{*} \mathrm{p}(\mathrm{M}+\mid \mathrm{FH}+)^{*} \mathrm{p}(\mathrm{TC}+\mid \mathrm{FH}+)^{*} \mathrm{p}(\mathrm{A} 2)^{*} \mathrm{p}(\mathrm{P} 2)$ \\
\hline False negatives & & \\
\hline $\mathrm{M}+$ & Yes & $\begin{array}{l}\mathrm{p}(\mathrm{FH}+)^{*} \mathrm{p}(\mathrm{A} 1)^{*} \mathrm{p}(\mathrm{P} 1)^{*} \mathrm{p}(\mathrm{M}+\mid \mathrm{FH}+)-\mathrm{p} \text { (true positive, } \mathrm{M}+\text { status } \\
\text { determined }\end{array}$
\end{tabular}




\begin{tabular}{|c|c|c|}
\hline $\mathrm{M}+$ & No & $\begin{array}{l}\left.\mathrm{p}(\mathrm{FH}+)^{*} \mathrm{p}(\mathrm{M}+\mid \mathrm{FH}+)-\mathrm{p} \text { (true positive, } \mathrm{M}+\text { status determined }\right)- \\
\mathrm{p}(\text { false negative, } \mathrm{M}+\text { status determined })\end{array}$ \\
\hline M- & Yes & $p(F H+)^{*} p(A 1) * p(P 1) * p(M-\mid F H+)$ \\
\hline M- & No & $\mathrm{p}(\mathrm{FH}+)^{*} \mathrm{p}(\mathrm{M}-\mid \mathrm{FH}+)-\mathrm{p}($ false negative, $\mathrm{M}$ - status determined) \\
\hline \multicolumn{3}{|c|}{ True negatives } \\
\hline $\mathrm{M}+$ & Yes & $\mathrm{p}(\mathrm{FH}-)^{*} \mathrm{p}(\mathrm{M}+\mid \mathrm{FH}-)-\mathrm{p}$ (true negative, $\mathrm{M}+$ status undetermined $)$ \\
\hline $\mathrm{M}+$ & No & $\begin{array}{l}\mathrm{p}(\mathrm{FH}-)^{*} \mathrm{p}(\mathrm{M}+\mid \mathrm{FH}-)^{*}(1-\mathrm{p}(\mathrm{A} 1))+\mathrm{p}(\mathrm{FH}-)^{*} \mathrm{p}(\mathrm{M}+\mid \mathrm{FH}-)^{*} \mathrm{p}(\mathrm{A} 1)^{*}(1-\mathrm{p}(\mathrm{P} 1))+ \\
\mathrm{p}(\mathrm{FH}-)^{*} \mathrm{p}(\mathrm{A} 1)^{*} \mathrm{p}(\mathrm{P} 1)^{*} \mathrm{p}(\mathrm{M}+\mid \mathrm{FH}-)^{*} \mathrm{p}(\mathrm{TC}+\mid \mathrm{FH}-)^{*}(1-\mathrm{p}(\mathrm{A} 2))+\mathrm{p}(\mathrm{FH}- \\
)^{*} \mathrm{p}(\mathrm{A} 1)^{*} \mathrm{p}(\mathrm{P} 1)^{*} \mathrm{p}(\mathrm{M}+\mid \mathrm{FH}-)^{*} \mathrm{p}(\mathrm{TC}+\mid \mathrm{FH}-)^{*} \mathrm{p}(\mathrm{A} 2)^{*}(1-\mathrm{p}(\mathrm{P} 2))\end{array}$ \\
\hline M- & Yes & $p(F H-)^{*} p(A 1) * p(P 1) * p(M-\mid F H-)$ \\
\hline M- & No & $\mathrm{p}(\mathrm{FH}-)^{*} \mathrm{p}(\mathrm{M}-\mid \mathrm{FH}-)-\mathrm{p}$ (true negative, $\mathrm{M}$ - status determined) \\
\hline
\end{tabular}

\section{Branch 4: sequential cholesterol-genetic screening}

\begin{tabular}{|c|c|c|}
\hline $\begin{array}{l}\text { Mutation } \\
\text { status }\end{array}$ & $\begin{array}{l}\text { Mutation status } \\
\text { determined }\end{array}$ & Formula \\
\hline \multicolumn{3}{|c|}{ True positives } \\
\hline$M+$ & Yes & $p(\mathrm{FH}+)^{*} p(\mathrm{~A} 1)^{*} p(\mathrm{P} 1)^{*} p(\mathrm{TC}+\mid \mathrm{FH}+)^{*} p(\mathrm{~A} 2)^{*} \mathrm{p}(\mathrm{P} 2)^{*} p(\mathrm{M}+\mid \mathrm{FH}+)$ \\
\hline $\mathrm{M}-$ & Yes & $p(F H+)^{*} p(A 1) * p(P 1) * p(T C+\mid F H+)^{*} p(A 2) * p(P 2) * p(M-\mid F H+)$ \\
\hline \multicolumn{3}{|c|}{ False negatives } \\
\hline$M+$ & No & $\mathrm{p}(\mathrm{FH}+)^{*} \mathrm{p}(\mathrm{M}+\mid \mathrm{FH}+)-\mathrm{p}$ (true positive, $\mathrm{M}+$ status determined) \\
\hline M- & No & $\mathrm{p}(\mathrm{FH}+)^{*} \mathrm{p}(\mathrm{M}-\mid \mathrm{FH}+)-\mathrm{p}($ true positive, $\mathrm{M}$ - status determined) \\
\hline \multicolumn{3}{|c|}{ True negatives } \\
\hline$M_{+}$ & No & $\mathrm{p}(\mathrm{FH}-)^{*} \mathrm{p}(\mathrm{M}+\mid \mathrm{FH}-)$ \\
\hline M- & Yes & $p(F H-)^{*} p(A 1)^{*} p(P 1)^{*} p(T C+\mid F H-)^{*} p(A 2)^{*} p(P 2)^{*} p(M-\mid T C+)$ \\
\hline M- & No & $\mathrm{p}(\mathrm{FH}-)^{*} \mathrm{p}(\mathrm{M}-\mid \mathrm{FH}-)-\mathrm{p}$ (true negative, $\mathrm{M}$ - status determined) \\
\hline
\end{tabular}

\section{Branch 5: parallel cholesterol-genetic screening}

\begin{tabular}{|c|c|c|}
\hline $\begin{array}{l}\text { Mutation } \\
\text { status }\end{array}$ & $\begin{array}{l}\text { Mutation status } \\
\text { determined }\end{array}$ & Formula \\
\hline \multicolumn{3}{|c|}{ True positives } \\
\hline $\mathrm{M}_{+}$ & Yes & $\mathrm{p}(\mathrm{FH}+)^{*} \mathrm{p}(\mathrm{A} 1) * \mathrm{p}(\mathrm{P} 1) * \mathrm{p}(\mathrm{M}+\mid \mathrm{FH}+)^{*} \mathrm{p}(\mathrm{TC}+\mid \mathrm{FH}+)^{*} \mathrm{p}(\mathrm{A} 2) * \mathrm{p}(\mathrm{P} 2)$ \\
\hline M- & Yes & $p(F H+)^{*} p(A 1) * p(P 1) * p(M-\mid F H+)^{*} p(T C+\mid F H+)^{*} p(A 2) * p(P 2)$ \\
\hline \multicolumn{3}{|c|}{ False negatives } \\
\hline $\mathrm{M}+$ & Yes & $\begin{array}{l}\mathrm{p}(\mathrm{FH}+)^{*} \mathrm{p}(\mathrm{A} 1)^{*} \mathrm{p}(\mathrm{P} 1)^{*}(\mathrm{M}+\mid \mathrm{FH}+)-\mathrm{p} \text { (true positive, } \mathrm{M}+\text { status } \\
\text { determined })\end{array}$ \\
\hline$M+$ & No & $\begin{array}{l}p(F H+) * p(M+\mid F H+)-p(\text { true positive, } M+\text { status determined })- \\
p(\text { false negative, } M+\text { status determined })\end{array}$ \\
\hline M- & Yes & $\begin{array}{l}\mathrm{p}(\mathrm{FH}+)^{*} \mathrm{p}(\mathrm{A} 1)^{*} \mathrm{p}(\mathrm{P} 1)^{*} \mathrm{p}(\mathrm{M}-\mid \mathrm{FH}+)-\mathrm{p}(\text { true positive, } \mathrm{M}-\text { status } \\
\text { determined })\end{array}$ \\
\hline M- & No & $\begin{array}{l}\mathrm{p}(\mathrm{FH}+)^{*} \mathrm{p}(\mathrm{M}-\mid \mathrm{FH}+)-\mathrm{p}(\text { true positive, } \mathrm{M} \text { - status determined })-\mathrm{p}(\text { false } \\
\text { negative, } \mathrm{M} \text { - status determined })\end{array}$ \\
\hline \multicolumn{3}{|c|}{ True negatives } \\
\hline $\mathrm{M}_{+}$ & Yes & $\mathrm{p}(\mathrm{FH}-)^{*} \mathrm{p}(\mathrm{A} 1)^{*} \mathrm{p}(\mathrm{P} 1)^{*} \mathrm{p}(\mathrm{M}+\mid \mathrm{FH}-)^{*} \mathrm{p}(\mathrm{TC}-\mid \mathrm{FH}-)$ \\
\hline $\mathrm{M}+$ & No & $\mathrm{p}(\mathrm{FH}-)^{*} \mathrm{p}(\mathrm{M}+\mid \mathrm{FH}-)-\mathrm{p}($ true negative, $\mathrm{M}+$ status determined $)$ \\
\hline M- & Yes & $p(F H-)^{*} p(A 1)^{*} p(P 1)^{*} p(M-\mid F H-)$ \\
\hline M- & No & $\mathrm{p}(\mathrm{FH}-)^{*} \mathrm{p}(\mathrm{M}-\mid \mathrm{FH}-)-\mathrm{p}($ true negative, $\mathrm{M}$ - status determined) \\
\hline
\end{tabular}




\section{Supplementary File 3: Markov model details}

Following estimation of case ascertainment under each screening strategy, the differential case ascertainment was described, with the individuals diagnosed under at least one strategy designated diagnosed or not, under each. A series of Markov models were designed to determine the average lifetime costs and effects associated with each designation (structure in Figure 1b). The models had annual cycles, with health state transitions at the start of each cycle, and all individuals entered in a 'well' health state (i.e. were without pre-existing CVD). Models were run separately for cohorts of 1,000 diagnosed or undiagnosed $\mathrm{FH}$ patients, with model entry at 2 years, 5 years, and each subsequent 5-year interval to 85 years.

US-identified individuals entered the model at 2 years. The age distribution of RCTidentified cases was presumed to follow that recently reported by the Welsh screening programme (in 0-19, 20-24, 25-34, 35-44, 45-54, 55-59, and 60-84 years categories; no individuals older than 84 years were identified; Kerr et al., 2017). And for modelling these cases were distributed equally across each of the Markov model start ages within the relevant age-category and that immediately above the upper limit of the category (to limit age underestimation).

\section{Transition probabilities}

Baseline annual primary CVD risks were estimated for each age-band by annualising the average of the 10-year QRISK2 estimates for all age-sex combinations within the age-band (Hippisley-Cox et al., 2008). The 10-year risks $\left(P_{10-y e a r}\right)$ were converted to rates using the formula:

$$
\text { rate }(r)=\left(-\ln \left(1-P_{10 \text {-year }}\right)\right) / 10
$$

and the calculated rates converted into annual risks ( $\left.P_{\text {annual }}\right)$ using the formula:

$$
P_{\text {annual }}=1-\mathrm{e}^{-r}
$$

As $\mathrm{FH}$ enhances $\mathrm{CHD}$ risk, but may not increase risk of cerebrovascular disease, the overall CVD risk estimates were disaggregated into constituent condition-specific risks using the multiplication factors described in CG181 (originally based on the Bromley CHD Register and Oxfordshire Community Stroke Project data). The resulting CVD death risk estimates were further split into CHD and non-CHD CVD estimates, according to the proportion of CVD deaths (deaths recorded under ICD10 codes G45, I20-25, I50, 160-64, and 173) attributed to CHD (recorded under codes I20-25) in the 2015 England and Wales Office for National Statistics (ONS) mortality database. For ages below those for which QRISK2 is valid (25-84 years), baseline CVD risks were estimated by adjusting the 25-29 years risks using the relative risks of 2013-14 HESrecorded inpatient CHD episodes (applied to angina, MI and CHD death), stroke episodes (for TIA and stroke), and non-CHD CVD episodes (for non-CHD CVD death), among those in the age-band of interest compared with the 25-29 years group. The relative risks were calculated using the episode counts for England reported by Bhatnagar et al (2016), and denominators from the 2013-14 ONS English population estimates. Risks for the 80-84 years group were similarly adjusted to achieve estimates for the $85+$ years group. It was assumed the relative $\mathrm{CHD}$ death risks described for the pre-treatment era Simon Broome cohort applied equally to fatal and non-fatal CHD, hence these were applied to the angina, MI and CHD death risks (Simon Broome Register Group, 1991). For age-bands below those for which relative risks were reported (20-79 years), the 20-39 year relative risk was applied (likely conservative as relative risk appears to decrease with age; Simon Broome Register Group, 1991) It was assumed those above 79 years did not experience any $\mathrm{FH}$ - 
associated CHD risk, as observed for the 60-79 years group (Simon Broome Register Group, 1991).

The secondary event risks described in CG181 were also applied without adjustment for $\mathrm{FH}$. These estimates were originally based on data from the Nottingham Heart Attack Register, South London Stroke Register, Juul-Moller et al, 1992, and the CURE trial. Undescribed required age-specific risks (for those $<40$ years) and CHD versus non-CHD CVD mortality risks, were estimated as described for primary CVD. As transition probabilities were not available for stable angina-stroke, unstable anginaunstable angina and TIA-unstable angina transitions, primary event risks were substituted. Primary event risks were also applied where they exceeded secondary event risks. It was assumed that probability of post-event state transitions to stable angina and TIA (i.e. improbable CHD regression) was zero. Non-CVD mortality risk was estimated using the 2015 England and Wales ONS mid-year population and nonCVD (i,e, total minus CVD) mortality figures. As HES data specific to the youngest modelled age-band were not available, it was assumed that CVD and mortality risks for this group were zero.

Treatment effects on transition probabilities were modelled as described in the main paper and Supplementary File 4. In the deterministic sensitivity analyses that involved modelling treatment discontinuation (see Table 3), it was assumed that transition probabilities reverted to untreated values immediately on discontinuation, which is likely conservative in view of treatment legacy effects (Ford et al., 2016). 


\section{Supplementary File 4: Details of modeled treatment}

As no $\mathrm{FH}$-associated risk was applied at $\geq 60$ years of age (in the Simon Broome cohort no FH effect was identified in this group; Simon Broome Register Group, 1991) FH treatment was modelled only to 60 years. Following the 2010 UK national FH management audit, LMT use was modelled for $85 \%$ of $\mathrm{FH}$-diagnosed adults in the base case (Pedersen et al, 2010). Modelled LMT regimes were also based on this audit, but with $40 \mathrm{mg} /$ day atorvastatin substituted for $80 \mathrm{mg} /$ day simvastatin regimes, in view of recent MHRA guidance to limit use of this regime (MHRA, 2010). It was therefore assumed that, among treated adults, $80 \%$ would use atorvastatin, $10 \%$ simvastatin, and $10 \%$ rosuvastatin, and that $46.3 \%$ would additionally use ezetimibe, with dose distribution as detailed below. It was assumed that children $<8$ years did not use LMT. Estimated proportions using LMT at 8-9 and 10-17 years were $23.1 \%$ and $57.6 \%$, as per recent report from the UK paediatric $\mathrm{FH}$ register, which also provided information about the nature of treatment (Ramaswami et al., 2017). It was assumed all treatment at $<10$ years was with low-dose pravastatin, with the remaining LMT regimes reported applicable to those 10-17 years - detailed below.

Proportions of treated persons using therapy

\begin{tabular}{lccc}
\cline { 2 - 4 } Daily therapy & $\mathbf{2 1 8}$ years & $\mathbf{1 0 - 1 7}$ years & $\mathbf{8 - 9}$ years \\
\hline Atorvastatin $10 \mathrm{mg}$ & 0.08 & 0.366 & 0 \\
Atorvastatin $20 \mathrm{mg}$ & 0.112 & 0.113 & 0 \\
Atorvastatin $40 \mathrm{mg}$ & 0.32 & 0.038 & 0 \\
Atorvastatin $80 \mathrm{mg}$ & 0.288 & 0.013 & 0 \\
\hline Rosuvastatin $5 \mathrm{mg}$ & 0.014 & 0.029 & 0 \\
Rosuvastatin $10 \mathrm{mg}$ & 0.025 & 0 & 0 \\
Rosuvastatin $20 \mathrm{mg}$ & 0.031 & 0 & 0 \\
Rosuvastatin $40 \mathrm{mg}$ & 0.03 & 0 & 0 \\
\hline Simvastatin $10 \mathrm{mg}$ & 0.008 & 0.162 & 0 \\
Simvastatin $20 \mathrm{mg}$ & 0.017 & 0.054 & 0 \\
Simvastatin $40 \mathrm{mg}$ & 0.075 & 0 & 0 \\
Simvastatin $80 \mathrm{mg}$ & 0 & 0 & 0 \\
\hline Pravastatin $10 \mathrm{mg}$ & 0 & 0.169 & 1.0 \\
Pravastatin $20 \mathrm{mg}$ & 0 & 0.056 & 0 \\
Pravastatin $40 \mathrm{mg}$ & 0 & 0 & 0 \\
\hline Ezetimibe $10 \mathrm{mg}$ & 0.463 & 0 & 0
\end{tabular}




\section{Supplementary File 5: Probability distributions assigned to sampled parameters and associated statistics}

aStandard errors estimated as $10 \%$ of the point estimate, as per previous models (NICE CG181; Ward et al, 2005) ${ }^{27} 53$; bNormal distribution was assigned to pre-treatment LDL-C estimates, as studies indicate such distribution (Starr et al., 2008, Wald et al., 2007), and Cl limits were sufficiently high to avoid risk of impossible negative values; SE: standard error; MI: myocardial infarction; TIA: transient ischaemic attack; FH: familial hypercholesterolaemia; CHD: coronary heart disease; LDL-C: low density lipoprotein cholesterol; LL: lower limit; UL: upper limit; Cl: confidence interval; SB: Simon Broome

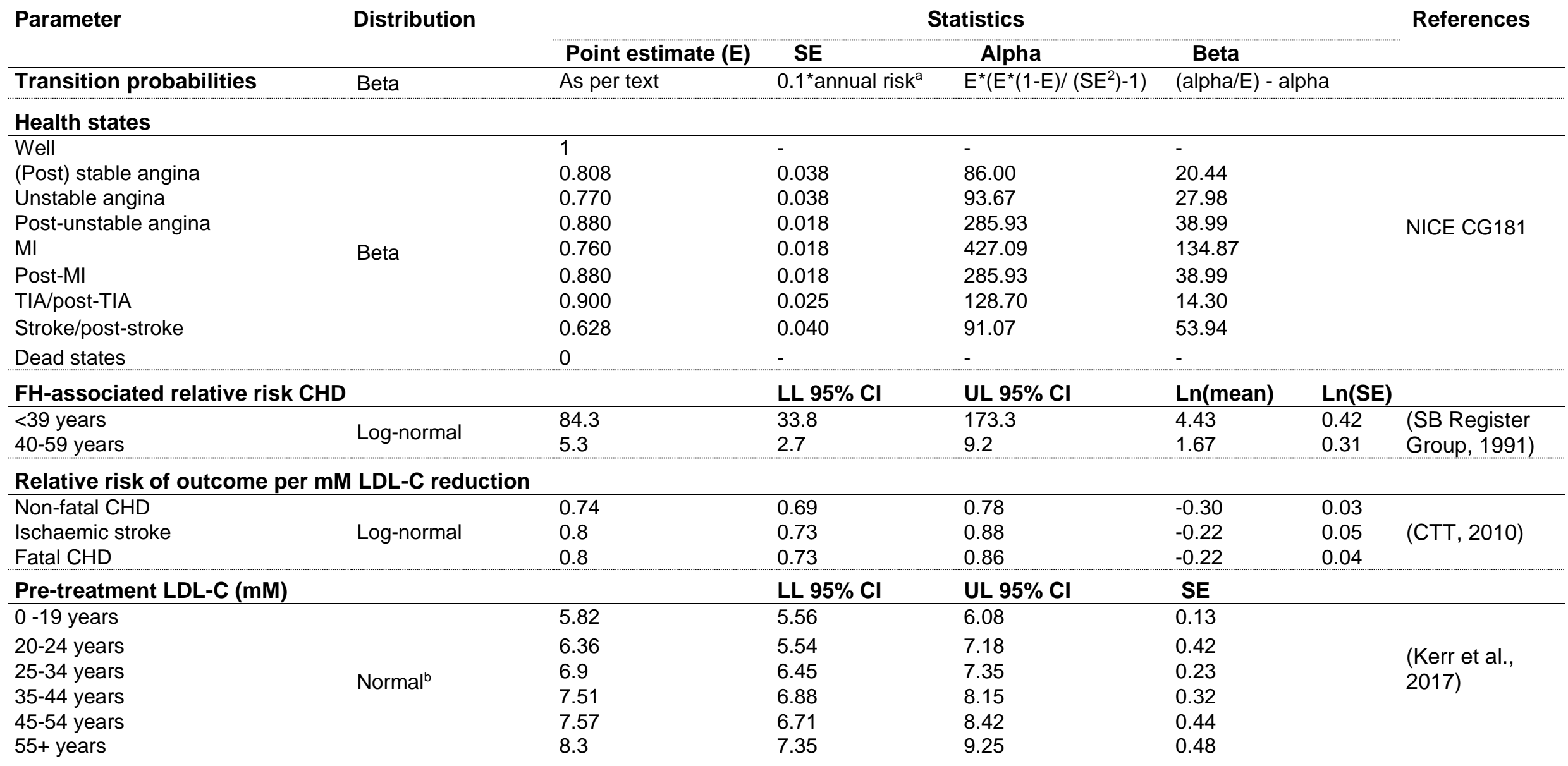




\section{Supplementary File 6: Familial hypercholesterolaemia case yields and costs per diagnosis under each screening strategy, as modelled in deterministic sensitivity analyses}

Results are presented for all scenarios where screening outcomes differ from the base case scenario

US: universal screening; RCT: reverse cascade testing

a. DSA adjustment: All $\mathrm{M}+$ defined as $\mathrm{FH}+$

\begin{tabular}{|c|c|c|c|c|c|c|}
\hline & \multicolumn{3}{|c|}{$\begin{array}{l}\text { FH cases identified per } \\
10,000 \text { screened in US }\end{array}$} & \multicolumn{3}{|c|}{$\begin{array}{l}\text { Screening costs per } \\
\text { diagnosis }(£)\end{array}$} \\
\hline & US & $\mathrm{RCT}$ & total & US & RCT & total \\
\hline No screening & 0 & 0 & 0 & $\mathrm{n} / \mathrm{a}$ & $\mathrm{n} / \mathrm{a}$ & $\mathrm{n} / \mathrm{a}$ \\
\hline Cholesterol-only screening & 22.38 & 0 & 22.38 & 11,788 & $\mathrm{n} / \mathrm{a}$ & 11,788 \\
\hline $\begin{array}{l}\text { Sequential genetic-cholesterol } \\
\text { screening }\end{array}$ & 14.05 & 0 & 14.05 & 176,742 & $\mathrm{n} / \mathrm{a}$ & 176,742 \\
\hline $\begin{array}{l}\text { Sequential cholesterol-genetic } \\
\text { screening }\end{array}$ & 24.41 & 0 & 24.41 & 13,785 & $\mathrm{n} / \mathrm{a}$ & 13,785 \\
\hline $\begin{array}{l}\text { Parallel cholesterol-genetic } \\
\text { screening }\end{array}$ & 28.04 & 0 & 28.04 & 89,751 & $\mathrm{n} / \mathrm{a}$ & 89,751 \\
\hline $\begin{array}{l}\text { Sequential genetic-cholesterol } \\
\text { screening plus RCT }\end{array}$ & 14.05 & 28.10 & 42.15 & 176,742 & 777 & 59,432 \\
\hline $\begin{array}{l}\text { Sequential cholesterol-genetic } \\
\text { screening plus RCT }\end{array}$ & 24.41 & 21.97 & 46.38 & 13,785 & 777 & 7,624 \\
\hline Parallel cholesterol-genetic & 28.04 & 28.10 & 56.14 & 89,751 & 777 & 45,212 \\
\hline
\end{tabular}

screening plus RCT

b. DSA adjustment: RCT case yield/index $=0.5$

\begin{tabular}{|c|c|c|c|c|c|c|}
\hline & \multicolumn{3}{|c|}{$\begin{array}{l}\text { FH cases identified per } \\
10,000 \text { screened }\end{array}$} & \multicolumn{3}{|c|}{$\begin{array}{l}\text { Screening costs per } \\
\text { diagnosis }(£)\end{array}$} \\
\hline & US & $\mathrm{RCT}$ & total & US & $\mathrm{RCT}$ & total \\
\hline No screening & 0 & 0 & 0 & $\mathrm{n} / \mathrm{a}$ & $\mathrm{n} / \mathrm{a}$ & $\mathrm{n} / \mathrm{a}$ \\
\hline Cholesterol-only screening & 22.38 & 0 & 22.38 & 11,788 & $\mathrm{n} / \mathrm{a}$ & 11,788 \\
\hline $\begin{array}{l}\text { Sequential genetic-cholesterol } \\
\text { screening }\end{array}$ & 11.44 & 0 & 11.44 & 217,036 & $\mathrm{n} / \mathrm{a}$ & 217,036 \\
\hline $\begin{array}{l}\text { Sequential cholesterol-genetic } \\
\text { screening }\end{array}$ & 24.41 & 0 & 24.41 & 13,785 & $\mathrm{n} / \mathrm{a}$ & 13,785 \\
\hline $\begin{array}{l}\text { Parallel cholesterol-genetic } \\
\text { screening }\end{array}$ & 25.43 & 0 & 25.43 & 98,959 & $\mathrm{n} / \mathrm{a}$ & 98,959 \\
\hline $\begin{array}{l}\text { Sequential genetic-cholesterol } \\
\text { screening plus RCT }\end{array}$ & 11.44 & 4.92 & 16.36 & 217,036 & 1,165 & 152,146 \\
\hline $\begin{array}{l}\text { Sequential cholesterol-genetic } \\
\text { screening plus RCT }\end{array}$ & 24.41 & 3.84 & 28.26 & 13,785 & 1,165 & 12,068 \\
\hline Parallel cholesterol-genetic & 25.43 & 4.92 & 30.35 & 98,959 & 1,165 & 83,110 \\
\hline
\end{tabular}

screening plus RCT 
c. DSA adjustment: RCT case yield/index $=6.1$

\begin{tabular}{lccccccc} 
& \multicolumn{3}{c}{$\begin{array}{c}\text { FH cases identified per } \\
\mathbf{1 0 , 0 0 0} \text { screened }\end{array}$} & \multicolumn{3}{c}{$\begin{array}{c}\text { Screening costs per } \\
\text { diagnosis }(\mathfrak{\Sigma})\end{array}$} \\
\cline { 2 - 8 } & US & RCT & total & US & RCT & total \\
\hline No screening & 0 & 0 & 0 & $\mathrm{n} / \mathrm{a}$ & $\mathrm{n} / \mathrm{a}$ & $\mathrm{n} / \mathrm{a}$ \\
\hline Cholesterol-only screening & 22.38 & 0 & 22.38 & 11,788 & $\mathrm{n} / \mathrm{a}$ & 11,788 \\
\hline $\begin{array}{l}\text { Sequential genetic-cholesterol } \\
\text { screening }\end{array}$ & 11.44 & 0 & 11.44 & 217,036 & $\mathrm{n} / \mathrm{a}$ & 217,036 \\
\hline $\begin{array}{l}\text { Sequential cholesterol-genetic } \\
\text { screening }\end{array}$ & 24.41 & 0 & 24.41 & 13,785 & $\mathrm{n} / \mathrm{a}$ & 13,785 \\
\hline $\begin{array}{l}\text { Parallel cholesterol-genetic } \\
\text { screening }\end{array}$ & 25.43 & 0 & 25.43 & 98,959 & $\mathrm{n} / \mathrm{a}$ & 98,959 \\
\hline $\begin{array}{l}\text { Sequential genetic-cholesterol } \\
\text { screening plus RCT }\end{array}$ & 11.44 & 60.00 & 71.44 & 217,036 & 1,098 & 35,684 \\
\hline $\begin{array}{l}\text { Sequential cholesterol-genetic } \\
\text { screening plus RCT }\end{array}$ & 24.41 & 46.91 & 71.32 & 13,785 & 1,098 & 5,441 \\
\hline $\begin{array}{l}\text { Parallel cholesterol-genetic } \\
\text { screening plus RCT }\end{array}$ & 25.43 & 60.00 & 85.43 & 98,959 & 1,098 & 30,227 \\
\end{tabular}

d. DSA adjustment: $\mathrm{RCT}$ case yield/index $=8.6$; probability relative $\mathrm{M}_{+}=0.31$

\begin{tabular}{|c|c|c|c|c|c|c|}
\hline & \multicolumn{3}{|c|}{$\begin{array}{l}\text { FH cases identified per } \\
10,000 \text { screened in US }\end{array}$} & \multicolumn{3}{|c|}{$\begin{array}{l}\text { Screening costs per } \\
\text { diagnosis }(£)\end{array}$} \\
\hline & US & $\mathrm{RCT}$ & total & US & $\mathrm{RCT}$ & total \\
\hline No screening & 0 & 0 & 0 & $\mathrm{n} / \mathrm{a}$ & $\mathrm{n} / \mathrm{a}$ & $\mathrm{n} / \mathrm{a}$ \\
\hline Cholesterol-only screening & 22.38 & 0 & 22.38 & 11,788 & $\mathrm{n} / \mathrm{a}$ & 11,788 \\
\hline $\begin{array}{l}\text { Sequential genetic-cholesterol } \\
\text { screening }\end{array}$ & 11.44 & 0 & 11.44 & 217,036 & $\mathrm{n} / \mathrm{a}$ & 217,036 \\
\hline $\begin{array}{l}\text { Sequential cholesterol-genetic } \\
\text { screening }\end{array}$ & 24.41 & 0 & 24.41 & 13,785 & $\mathrm{n} / \mathrm{a}$ & 13,785 \\
\hline $\begin{array}{l}\text { Parallel cholesterol-genetic } \\
\text { screening }\end{array}$ & 25.43 & 0 & 25.43 & 98,959 & $\mathrm{n} / \mathrm{a}$ & 98,959 \\
\hline $\begin{array}{l}\text { Sequential genetic-cholesterol } \\
\text { screening plus RCT }\end{array}$ & 11.44 & 84.59 & 96.03 & 217,036 & 1,414 & 27,106 \\
\hline $\begin{array}{l}\text { Sequential cholesterol-genetic } \\
\text { screening plus RCT }\end{array}$ & 24.41 & 66.13 & 90.54 & 13,785 & 1,414 & 4,749 \\
\hline $\begin{array}{l}\text { Parallel cholesterol-genetic } \\
\text { screening plus } \mathrm{RCT}\end{array}$ & 25.43 & 84.59 & 110.02 & 98,959 & 1,414 & 23,959 \\
\hline
\end{tabular}


e. DSA adjustment: $\mathrm{RCT}$ case yield/index $=8.6$; probability relative $\mathrm{M}_{+}=0.21$

\begin{tabular}{|c|c|c|c|c|c|c|}
\hline & \multicolumn{3}{|c|}{$\begin{array}{l}\text { FH cases identified per } \\
10,000 \text { screened in US }\end{array}$} & \multicolumn{3}{|c|}{$\begin{array}{l}\text { Screening costs per } \\
\text { diagnosis }(£)\end{array}$} \\
\hline & US & $\mathrm{RCT}$ & total & US & $\mathrm{RCT}$ & total \\
\hline No screening & 0 & 0 & 0 & $\mathrm{n} / \mathrm{a}$ & $\mathrm{n} / \mathrm{a}$ & $\mathrm{n} / \mathrm{a}$ \\
\hline Cholesterol-only screening & 22.38 & 0 & 22.38 & 11,788 & $\mathrm{n} / \mathrm{a}$ & 11,788 \\
\hline $\begin{array}{l}\text { Sequential genetic-cholesterol } \\
\text { screening }\end{array}$ & 11.44 & 0 & 11.44 & 217,036 & $\mathrm{n} / \mathrm{a}$ & 217,036 \\
\hline $\begin{array}{l}\text { Sequential cholesterol-genetic } \\
\text { screening }\end{array}$ & 24.41 & 0 & 24.41 & 13,785 & $\mathrm{n} / \mathrm{a}$ & 13,785 \\
\hline $\begin{array}{l}\text { Parallel cholesterol-genetic } \\
\text { screening }\end{array}$ & 25.43 & 0 & 25.43 & 98,959 & $\mathrm{n} / \mathrm{a}$ & 98,959 \\
\hline $\begin{array}{l}\text { Sequential genetic-cholesterol } \\
\text { screening plus RCT }\end{array}$ & 11.44 & 84.59 & 96.03 & 217,036 & 2.049 & 27,666 \\
\hline $\begin{array}{l}\text { Sequential cholesterol-genetic } \\
\text { screening plus RCT }\end{array}$ & 24.41 & 66.13 & 90.54 & 13,785 & 2.049 & 5,213 \\
\hline $\begin{array}{l}\text { Parallel cholesterol-genetic } \\
\text { screening plus RCT }\end{array}$ & 25.43 & 84.59 & 110.02 & 98,959 & 2.049 & 24,448 \\
\hline
\end{tabular}

f. DSA adjustment: Cholesterol test true positive rate for sequential cholesterolgenetic US strategy $=62.5 \%$

${ }^{*}$ NB. Cholesterol-only cholesterol threshold not adjusted in DSA as not clear that performance would be acceptable even using thresholds of highest described posttest probability $(=0.53)$ in recent analysis, and not of concern as strategy dominated even at base case performance for this strategy (see Supplementary File 7, Table r)

\begin{tabular}{|c|c|c|c|c|c|c|}
\hline & \multicolumn{3}{|c|}{$\begin{array}{l}\text { FH cases identified per } \\
10,000 \text { screened in US }\end{array}$} & \multicolumn{3}{|c|}{$\begin{array}{l}\text { Screening costs per } \\
\text { diagnosis }(£)\end{array}$} \\
\hline & US & $\mathrm{RCT}$ & total & US & $\mathrm{RCT}$ & total \\
\hline No screening & 0 & 0 & 0 & $\mathrm{n} / \mathrm{a}$ & $\mathrm{n} / \mathrm{a}$ & $\mathrm{n} / \mathrm{a}$ \\
\hline Cholesterol-only screening* & 22.38 & 0 & 22.38 & 11,788 & $\mathrm{n} / \mathrm{a}$ & 11,788 \\
\hline $\begin{array}{l}\text { Sequential genetic-cholesterol } \\
\text { screening }\end{array}$ & 11.44 & 0 & 11.44 & 217,036 & $\mathrm{n} / \mathrm{a}$ & 217,036 \\
\hline $\begin{array}{l}\text { Sequential cholesterol-genetic } \\
\text { screening }\end{array}$ & 15.89 & 0 & 15.89 & 21,023 & $\mathrm{n} / \mathrm{a}$ & 21,023 \\
\hline $\begin{array}{l}\text { Parallel cholesterol-genetic } \\
\text { screening }\end{array}$ & 25.43 & 0 & 25.43 & 98,959 & $\mathrm{n} / \mathrm{a}$ & 98,959 \\
\hline $\begin{array}{l}\text { Sequential genetic-cholesterol } \\
\text { screening plus RCT }\end{array}$ & 11.44 & 19.67 & 31.11 & 217,036 & 1,110 & 80,519 \\
\hline $\begin{array}{l}\text { Sequential cholesterol-genetic } \\
\text { screening plus RCT }\end{array}$ & 15.89 & 10.01 & 25.90 & 21,023 & 1,110 & 13,327 \\
\hline $\begin{array}{l}\text { Parallel cholesterol-genetic } \\
\text { screening plus RCT }\end{array}$ & 25.43 & 19.67 & 45.10 & 98,959 & 1,110 & 56,279 \\
\hline
\end{tabular}


g. DSA adjustment: Universal screening appointment duration $=40$ minutes

\begin{tabular}{|c|c|c|c|c|c|c|}
\hline & \multicolumn{3}{|c|}{$\begin{array}{l}\text { FH cases identified per } \\
10,000 \text { screened in US }\end{array}$} & \multicolumn{3}{|c|}{$\begin{array}{l}\text { Screening costs per } \\
\text { diagnosis }(£)\end{array}$} \\
\hline & US & $\mathrm{RCT}$ & total & US & $\mathrm{RCT}$ & total \\
\hline No screening & 0 & 0 & 0 & $\mathrm{n} / \mathrm{a}$ & $\mathrm{n} / \mathrm{a}$ & $\mathrm{n} / \mathrm{a}$ \\
\hline Cholesterol-only screening & 22.38 & 0 & 22.38 & 14,127 & $\mathrm{n} / \mathrm{a}$ & 14,127 \\
\hline $\begin{array}{l}\text { Sequential genetic-cholesterol } \\
\text { screening }\end{array}$ & 11.44 & 0 & 11.44 & 221,611 & $\mathrm{n} / \mathrm{a}$ & 221,611 \\
\hline $\begin{array}{l}\text { Sequential cholesterol-genetic } \\
\text { screening }\end{array}$ & 24.41 & 0 & 24.41 & 15,930 & $\mathrm{n} / \mathrm{a}$ & 15,930 \\
\hline $\begin{array}{l}\text { Parallel cholesterol-genetic } \\
\text { screening }\end{array}$ & 25.43 & 0 & 25.43 & 101,018 & $\mathrm{n} / \mathrm{a}$ & 101,018 \\
\hline $\begin{array}{l}\text { Sequential genetic-cholesterol } \\
\text { screening plus RCT }\end{array}$ & 11.44 & 19.67 & 31.11 & 221,611 & 1,110 & 82,201 \\
\hline $\begin{array}{l}\text { Sequential cholesterol-genetic } \\
\text { screening plus RCT }\end{array}$ & 24.41 & 15.38 & 39.79 & 15,930 & 1,110 & 10,202 \\
\hline $\begin{array}{l}\text { Parallel cholesterol-genetic } \\
\text { screening plus RCT }\end{array}$ & 25.43 & 19.67 & 45.10 & 101,018 & 1,110 & 57,439 \\
\hline
\end{tabular}




\section{Supplementary File 7: Deterministic sensitivity analysis incremental cost effectiveness ratio comparisons \\ QALY: quality adjusted life year; ICER: incremental cost-effectiveness ratio; RCT: reverse cascade testing; SD: strongly dominated}

a. DSA adjustment: Costs for treatment of false positives included

\begin{tabular}{lccccc} 
& & & & ICER (£/QALY) \\
\cline { 5 - 6 } & QALYs & Costs $(\boldsymbol{E})$ & $\begin{array}{c}\text { versus no } \\
\text { screening }\end{array}$ & $\begin{array}{c}\text { versus next } \\
\text { lowest cost }\end{array}$ & $\begin{array}{c}\text { versus relevant } \\
\text { alternative }\end{array}$ \\
\hline No screening & 991.8 & 225,983 & - & - & - \\
\hline Cholesterol-only screening & $1,009.2$ & 601,172 & 21,608 & 21,608 & ED \\
\hline $\begin{array}{l}\text { Sequential cholesterol-genetic } \\
\text { screening }\end{array}$ & $1,010.7$ & 640,288 & 21,872 & 24,781 & ED \\
\hline $\begin{array}{l}\text { Sequential cholesterol-genetic } \\
\text { screening plus RCT }\end{array}$ & $1,027.5$ & 672,362 & 12,480 & 1,906 & 12,480 \\
\hline $\begin{array}{l}\text { Sequential genetic-cholesterol } \\
\text { screening }\end{array}$ & $1,000.7$ & $2,745,892$ & 283,799 & SD & SD \\
\hline $\begin{array}{l}\text { Sequential genetic-cholesterol } \\
\text { screening plus RCT }\end{array}$ & $1,022.2$ & $2,786,918$ & 84,240 & SD & SD \\
\hline $\begin{array}{l}\text { Parallel cholesterol-genetic } \\
\text { screening }\end{array}$ & $1,011.5$ & $2,823,343$ & 131,635 & SD & SD \\
\hline $\begin{array}{l}\text { Parallel cholesterol-genetic } \\
\text { screening plus RCT }\end{array}$ & $1,033.0$ & $2,864,370$ & 63,957 & 399,581 & 399,581 \\
\hline
\end{tabular}

b. DSA adjustment: All $\mathrm{M}+$ defined as $\mathrm{FH}+$

ICER (£/QALY)

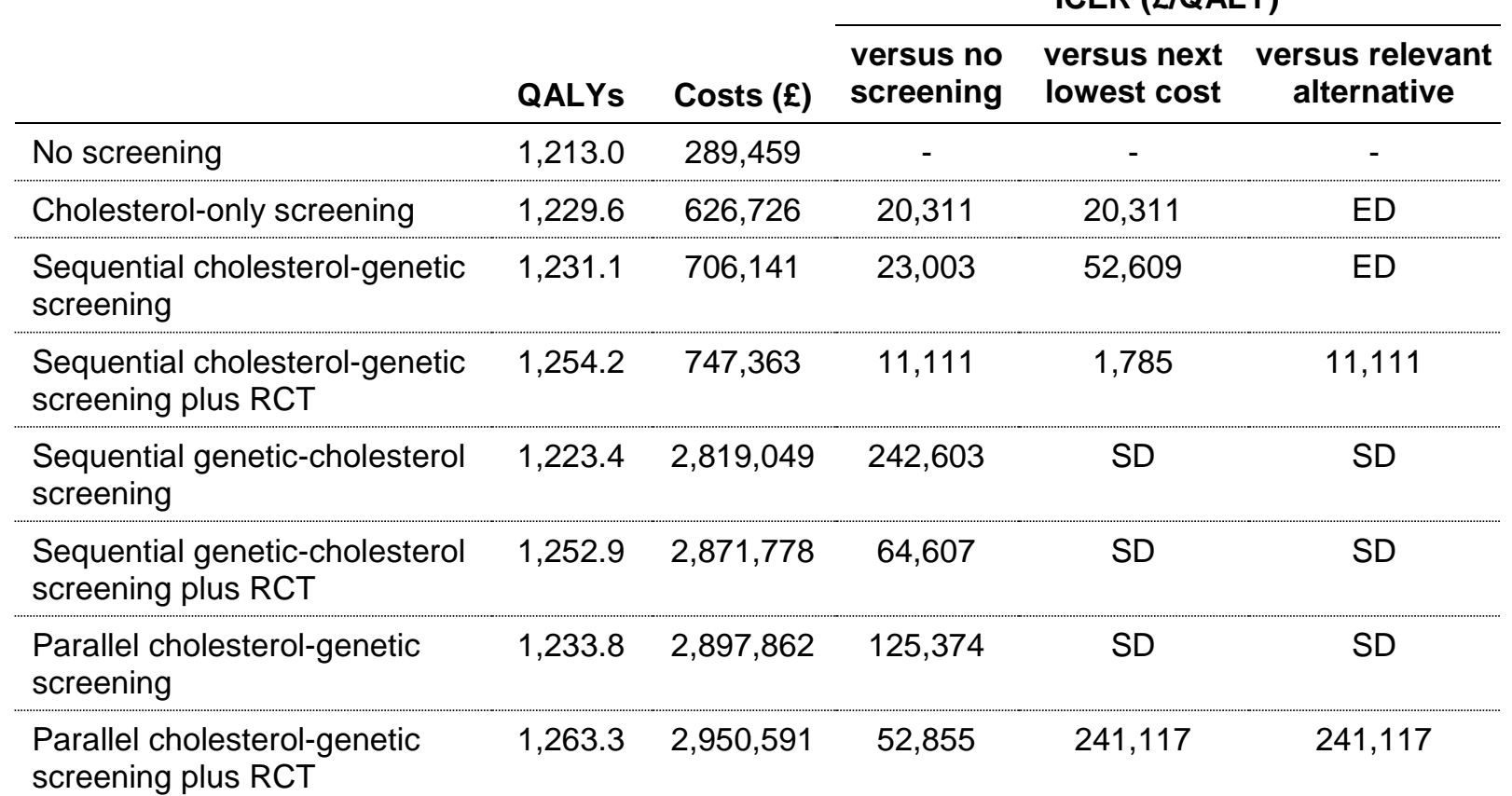


c. DSA adjustment: RCT case yield/index $=0.5$

\begin{tabular}{|c|c|c|c|c|c|}
\hline & \multirow[b]{2}{*}{ QALYS } & \multirow[b]{2}{*}{ Costs (£) } & \multicolumn{3}{|c|}{ ICER (£/QALY) } \\
\hline & & & $\begin{array}{l}\text { versus no } \\
\text { screening }\end{array}$ & $\begin{array}{l}\text { versus next } \\
\text { lowest cost }\end{array}$ & $\begin{array}{l}\text { versus relevant } \\
\text { alternative }\end{array}$ \\
\hline No screening & 715.0 & 136,062 & - & - & - \\
\hline Cholesterol-only screening & 732.3 & 471,151 & 19,298 & 19,298 & ED \\
\hline $\begin{array}{l}\text { Sequential cholesterol- } \\
\text { genetic screening }\end{array}$ & 733.9 & 550,368 & 21,872 & 50,184 & ED \\
\hline $\begin{array}{l}\text { Sequential cholesterol- } \\
\text { genetic screening plus RCT }\end{array}$ & 738.1 & 558,597 & 18,253 & 1,956 & 18,253 \\
\hline $\begin{array}{l}\text { Sequential genetic- } \\
\text { cholesterol screening }\end{array}$ & 723.9 & $2,655,971$ & 283,799 & SD & SD \\
\hline $\begin{array}{l}\text { Sequential genetic- } \\
\text { cholesterol screening plus } \\
\text { RCT }\end{array}$ & 729.2 & $2,666,498$ & 177,456 & SD & SD \\
\hline $\begin{array}{l}\text { Parallel cholesterol-genetic } \\
\text { screening }\end{array}$ & 734.7 & $2,733,423$ & 131,635 & SD & SD \\
\hline $\begin{array}{l}\text { Parallel cholesterol-genetic } \\
\text { screening plus RCT }\end{array}$ & 740.1 & $2,743,949$ & 103,851 & $1,113,050$ & $1,113,050$ \\
\hline
\end{tabular}

d. DSA adjustment: RCT case yield/index $=6.1$

ICER (£/QALY)

\begin{tabular}{|c|c|c|c|c|c|}
\hline & QALYs & Costs (£) & $\begin{array}{l}\text { versus no } \\
\text { screening }\end{array}$ & $\begin{array}{l}\text { versus next } \\
\text { lowest cost }\end{array}$ & $\begin{array}{l}\text { versus relevant } \\
\text { alternative }\end{array}$ \\
\hline No screening & $1,748.4$ & 471,765 & - & - & - \\
\hline Cholesterol-only screening & $1,765.7$ & 806,854 & 19,298 & 19,298 & ED \\
\hline $\begin{array}{l}\text { Sequential cholesterol-genetic } \\
\text { screening }\end{array}$ & $1,767.3$ & 886,071 & 21,872 & 50,184 & ED \\
\hline $\begin{array}{l}\text { Sequential cholesterol-genetic } \\
\text { screening plus RCT }\end{array}$ & $1,818.6$ & 983,318 & 7,281 & 1,895 & 7,281 \\
\hline $\begin{array}{l}\text { Sequential genetic-cholesterol } \\
\text { screening }\end{array}$ & $1,757.2$ & $2,991,674$ & 283,799 & SD & SD \\
\hline $\begin{array}{l}\text { Parallel cholesterol-genetic } \\
\text { screening }\end{array}$ & $1,768.1$ & $3,069,125$ & 131,635 & SD & SD \\
\hline $\begin{array}{l}\text { Sequential genetic-cholesterol } \\
\text { screening plus RCT }\end{array}$ & $1,822.9$ & $3,116,067$ & 35,485 & 500,499 & ED \\
\hline $\begin{array}{l}\text { Parallel cholesterol-genetic } \\
\text { screening plus RCT }\end{array}$ & $1,833.7$ & $3,193,519$ & 31,881 & 7,137 & 146,239 \\
\hline
\end{tabular}


e. DSA adjustment: $\mathrm{RCT}$ case yield/index $=8.6$; probability relative $\mathrm{M}_{+}=0.31$

\begin{tabular}{|c|c|c|c|c|c|}
\hline & \multirow[b]{2}{*}{ QALYs } & \multirow[b]{2}{*}{ Costs (£) } & \multicolumn{3}{|c|}{ ICER (£/QALY) } \\
\hline & & & $\begin{array}{l}\text { versus no } \\
\text { screening }\end{array}$ & $\begin{array}{l}\text { versus next } \\
\text { lowest cost }\end{array}$ & $\begin{array}{l}\text { versus relevant } \\
\text { alternative }\end{array}$ \\
\hline No screening & $2,209.7$ & 621,632 & - & - & - \\
\hline Cholesterol-only screening & $2,227.1$ & 956,721 & 19,298 & 19,298 & ED \\
\hline $\begin{array}{l}\text { Sequential cholesterol-genetic } \\
\text { screening }\end{array}$ & $2,228.7$ & $1,035,938$ & 21,872 & 50,184 & ED \\
\hline $\begin{array}{l}\text { Sequential cholesterol-genetic } \\
\text { screening plus RCT }\end{array}$ & $2,301.0$ & $1,193,919$ & 6,269 & 2,184 & 6,269 \\
\hline $\begin{array}{l}\text { Sequential genetic-cholesterol } \\
\text { screening }\end{array}$ & $2,218.6$ & $3,141,541$ & 283,799 & SD & SD \\
\hline $\begin{array}{l}\text { Parallel cholesterol-genetic } \\
\text { screening }\end{array}$ & $2,229.4$ & $3,218,993$ & 131,635 & SD & SD \\
\hline $\begin{array}{l}\text { Sequential genetic-cholesterol } \\
\text { screening plus RCT }\end{array}$ & $2,311.1$ & $3,343,622$ & 26,839 & 212,172 & ED \\
\hline $\begin{array}{l}\text { Parallel cholesterol-genetic } \\
\text { screening plus RCT }\end{array}$ & $2,322.0$ & $3,421,074$ & 24,934 & 7,137 & 106,135 \\
\hline
\end{tabular}

f. DSA adjustment: $\mathrm{RCT}$ case yield/index $=8.6$; probability relative $\mathrm{M}_{+}=0.21$

\begin{tabular}{|c|c|c|c|c|c|}
\hline & \multirow[b]{2}{*}{ QALYs } & \multirow[b]{2}{*}{ Costs $(£)$} & \multicolumn{3}{|c|}{ ICER (£/QALY) } \\
\hline & & & $\begin{array}{l}\text { versus no } \\
\text { screening }\end{array}$ & $\begin{array}{l}\text { versus next } \\
\text { lowest cost }\end{array}$ & $\begin{array}{l}\text { versus relevant } \\
\text { alternative }\end{array}$ \\
\hline No screening & $2,209.7$ & 621,632 & - & - & - \\
\hline Cholesterol-only screening & $2,227.1$ & 956,721 & 19,298 & 19,298 & ED \\
\hline $\begin{array}{l}\text { Sequential cholesterol-genetic } \\
\text { screening }\end{array}$ & $2,228.7$ & $1,035,938$ & 21,872 & 50,184 & ED \\
\hline $\begin{array}{l}\text { Sequential cholesterol-genetic } \\
\text { screening plus RCT }\end{array}$ & $2,301.0$ & $1,235,907$ & 6,729 & 2,764 & 6,729 \\
\hline $\begin{array}{l}\text { Sequential genetic-cholesterol } \\
\text { screening }\end{array}$ & $2,218.6$ & $3,141,541$ & 283,799 & SD & SD \\
\hline $\begin{array}{l}\text { Parallel cholesterol-genetic } \\
\text { screening }\end{array}$ & $2,229.4$ & $3,218,993$ & 131,635 & SD & SD \\
\hline $\begin{array}{l}\text { Sequential genetic-cholesterol } \\
\text { screening plus RCT }\end{array}$ & $2,311.1$ & $3,397,331$ & 27,368 & 213,329 & ED \\
\hline $\begin{array}{l}\text { Parallel cholesterol-genetic } \\
\text { screening plus RCT }\end{array}$ & $2,322.0$ & $3,474,782$ & 25,413 & 7,137 & 106,693 \\
\hline
\end{tabular}


g. DSA adjustment: $100 \%$ of diagnosed adults treated

\begin{tabular}{|c|c|c|c|c|c|}
\hline & \multirow[b]{2}{*}{ QALYs } & \multirow[b]{2}{*}{ Costs (£) } & \multicolumn{3}{|c|}{ ICER (£/QALY) } \\
\hline & & & $\begin{array}{l}\text { versus no } \\
\text { screening }\end{array}$ & $\begin{array}{l}\text { versus next } \\
\text { lowest cost }\end{array}$ & $\begin{array}{l}\text { versus relevant } \\
\text { alternative }\end{array}$ \\
\hline No screening & 991.8 & 225,983 & - & - & \\
\hline Cholesterol-only screening & $1,012.0$ & 565,780 & 16,776 & 16,776 & ED \\
\hline $\begin{array}{l}\text { Sequential cholesterol-genetic } \\
\text { screening }\end{array}$ & $1,013.9$ & 645,425 & 18,982 & 43,253 & ED \\
\hline $\begin{array}{l}\text { Sequential cholesterol-genetic } \\
\text { screening plus } \mathrm{RCT}\end{array}$ & $1,033.6$ & 679,495 & 10,832 & 1,723 & 10,832 \\
\hline $\begin{array}{l}\text { Sequential genetic-cholesterol } \\
\text { screening }\end{array}$ & $1,002.1$ & $2,748,299$ & 243,521 & SD & SD \\
\hline $\begin{array}{l}\text { Sequential genetic-cholesterol } \\
\text { screening plus RCT }\end{array}$ & $1,027.4$ & $2,791,880$ & 71,981 & SD & SD \\
\hline $\begin{array}{l}\text { Parallel cholesterol-genetic } \\
\text { screening }\end{array}$ & $1,014.8$ & $2,828,694$ & 113,077 & SD & SD \\
\hline $\begin{array}{l}\text { Parallel cholesterol-genetic } \\
\text { screening plus RCT }\end{array}$ & $1,040.1$ & $2,872,274$ & 54,782 & 340,523 & 340,523 \\
\hline
\end{tabular}

h. DSA adjustment: $100 \%$ of diagnosed treated from 8 years

\begin{tabular}{|c|c|c|c|c|c|}
\hline & \multirow[b]{2}{*}{ QALYs } & \multirow[b]{2}{*}{ Costs $(£)$} & \multicolumn{3}{|c|}{ ICER (£/QALY) } \\
\hline & & & $\begin{array}{l}\text { versus no } \\
\text { screening }\end{array}$ & $\begin{array}{l}\text { versus next } \\
\text { lowest cost }\end{array}$ & $\begin{array}{l}\text { versus relevant } \\
\text { alternative }\end{array}$ \\
\hline No screening & 991.8 & 225,983 & - & - & - \\
\hline Cholesterol-only screening & $1,012.8$ & 566,626 & 16,209 & 16,209 & ED \\
\hline $\begin{array}{l}\text { Sequential cholesterol-genetic } \\
\text { screening }\end{array}$ & $1,014.7$ & 646,348 & 18,335 & 41,727 & ED \\
\hline $\begin{array}{l}\text { Sequential cholesterol-genetic } \\
\text { screening plus RCT }\end{array}$ & $1,034.6$ & 680,443 & 10,619 & 1,716 & 10,619 \\
\hline $\begin{array}{l}\text { Sequential genetic-cholesterol } \\
\text { screening }\end{array}$ & $1,002.5$ & $2,748,732$ & 234,744 & SD & SD \\
\hline $\begin{array}{l}\text { Sequential genetic-cholesterol } \\
\text { screening plus RCT }\end{array}$ & $1,027.9$ & $2,792,344$ & 70,963 & SD & SD \\
\hline $\begin{array}{l}\text { Parallel cholesterol-genetic } \\
\text { screening }\end{array}$ & $1,015.7$ & $2,829,655$ & 109,023 & SD & SD \\
\hline $\begin{array}{l}\text { Parallel cholesterol-genetic } \\
\text { screening plus RCT }\end{array}$ & $1,041.1$ & $2,873,268$ & 53,698 & 337,246 & 337,246 \\
\hline
\end{tabular}




\begin{tabular}{|c|c|c|c|c|c|}
\hline & \multirow[b]{2}{*}{ QALYs } & \multirow[b]{2}{*}{ Costs $(£)$} & \multicolumn{3}{|c|}{ ICER (£/QALY) } \\
\hline & & & $\begin{array}{l}\text { versus no } \\
\text { screening }\end{array}$ & $\begin{array}{l}\text { versus next } \\
\text { lowest cost }\end{array}$ & $\begin{array}{l}\text { versus relevant } \\
\text { alternative }\end{array}$ \\
\hline No screening & 991.8 & 225,983 & - & - & - \\
\hline Cholesterol-only screening & $1,006.8$ & 558,312 & 22,177 & 22,177 & ED \\
\hline $\begin{array}{l}\text { Sequential cholesterol-genetic } \\
\text { screening }\end{array}$ & $1,008.1$ & 637,278 & 25,159 & 57,965 & ED \\
\hline $\begin{array}{l}\text { Sequential cholesterol-genetic } \\
\text { screening plus RCT }\end{array}$ & $1,023.6$ & 668,645 & 13,927 & 2,032 & 13,927 \\
\hline $\begin{array}{l}\text { Sequential genetic-cholesterol } \\
\text { screening }\end{array}$ & 999.4 & $2,744,480$ & 328,656 & SD & SD \\
\hline $\begin{array}{l}\text { Sequential genetic-cholesterol } \\
\text { screening plus RCT }\end{array}$ & $1,019.2$ & $2,784,604$ & 93,347 & SD & SD \\
\hline $\begin{array}{l}\text { Parallel cholesterol-genetic } \\
\text { screening }\end{array}$ & $1,008.8$ & $2,820,207$ & 152,342 & SD & SD \\
\hline $\begin{array}{l}\text { Parallel cholesterol-genetic } \\
\text { screening plus RCT }\end{array}$ & $1,028.6$ & $2,860,331$ & 71,633 & 439,178 & 439,178 \\
\hline
\end{tabular}

j. DSA adjustment: 50\% LDL-C reduction achieved with LMT

\begin{tabular}{lccccc} 
& & & \multicolumn{3}{c}{ ICER (£/QALY) } \\
\cline { 3 - 6 } & QALYs & Costs $(£)$ & $\begin{array}{c}\text { versus no } \\
\text { screening }\end{array}$ & $\begin{array}{c}\text { versus next } \\
\text { lowest cost }\end{array}$ & $\begin{array}{c}\text { versus relevant } \\
\text { alternative }\end{array}$ \\
\hline No screening & 992.5 & 224,945 & - & - & - \\
\hline Cholesterol-only screening & $1,018.1$ & 538,673 & 12,272 & 12,272 & ED \\
\hline $\begin{array}{l}\text { Sequential cholesterol-genetic } \\
\text { screening }\end{array}$ & $1,020.4$ & 615,958 & 14,020 & 33,249 & ED \\
\hline $\begin{array}{l}\text { Sequential cholesterol-genetic } \\
\text { screening plus RCT }\end{array}$ & $1,044.7$ & 628,769 & 7,733 & 527 & 7,733 \\
\hline $\begin{array}{l}\text { Sequential genetic-cholesterol } \\
\text { screening }\end{array}$ & $1,005.6$ & $2,733,931$ & 191,917 & SD & SD \\
\hline $\begin{array}{l}\text { Sequential genetic-cholesterol } \\
\text { screening plus RCT }\end{array}$ & $1,036.7$ & $2,750,330$ & 57,140 & SD & SD \\
\hline $\begin{array}{l}\text { Parallel cholesterol-genetic } \\
\text { screening }\end{array}$ & $1,021.6$ & $2,798,032$ & 88,569 & SD & SD \\
\hline $\begin{array}{l}\text { Parallel cholesterol-genetic } \\
\text { screening plus RCT }\end{array}$ & $1,052.7$ & $2,814,431$ & 43,032 & 274,785 & 274,785 \\
& & & & & \\
\hline
\end{tabular}


k. DSA adjustment: Estimated off-patent LMT costs applied

ICER (£/QALY)

\begin{tabular}{lccccc} 
& QALYs & Costs $(£)$ & $\begin{array}{c}\text { versus no } \\
\text { screening }\end{array}$ & $\begin{array}{c}\text { versus next } \\
\text { lowest cost }\end{array}$ & $\begin{array}{c}\text { versus relevant } \\
\text { alternative }\end{array}$ \\
\hline No screening & 992.8 & 224,417 & - & - & \\
\hline Cholesterol-only screening & $1,009.8$ & 519,575 & 17,276 & 17,276 & ED \\
\hline $\begin{array}{l}\text { Sequential cholesterol-genetic } \\
\text { screening }\end{array}$ & $1,011.4$ & 595,162 & 19,892 & 48,666 & ED \\
\hline $\begin{array}{l}\text { Sequential cholesterol-genetic } \\
\text { screening plus RCT }\end{array}$ & $1,028.0$ & 597,766 & 10,600 & 157 & 10,600 \\
\hline $\begin{array}{l}\text { Sequential genetic-cholesterol } \\
\text { screening }\end{array}$ & $1,001.5$ & $2,723,907$ & 286,093 & SD & SD \\
\hline $\begin{array}{l}\text { Sequential genetic-cholesterol } \\
\text { screening plus RCT }\end{array}$ & $1,022.7$ & $2,727,237$ & 83,569 & SD & SD \\
\hline $\begin{array}{l}\text { Parallel cholesterol-genetic } \\
\text { screening }\end{array}$ & $1,012.2$ & $2,776,402$ & 131,446 & SD & SD \\
\hline $\begin{array}{l}\text { Parallel cholesterol-genetic } \\
\text { screening plus RCT }\end{array}$ & $1,033.4$ & $2,779,732$ & 62,897 & 403,638 & 403,638 \\
\hline
\end{tabular}

I. DSA adjustment: Discount rate $=1.5 \%$

ICER (£/QALY)

\begin{tabular}{|c|c|c|c|c|c|}
\hline & QALYs & Costs (£) & $\begin{array}{l}\text { versus no } \\
\text { screening }\end{array}$ & $\begin{array}{l}\text { versus next } \\
\text { lowest cost }\end{array}$ & $\begin{array}{l}\text { versus relevant } \\
\text { alternative }\end{array}$ \\
\hline No screening & $1,552.0$ & 458,095 & - & - & - \\
\hline Cholesterol-only screening & $1,600.9$ & 809,893 & 7,193 & 7,193 & ED \\
\hline $\begin{array}{l}\text { Sequential cholesterol-genetic } \\
\text { screening }\end{array}$ & $1,605.4$ & 890,629 & 8,107 & 18,158 & ED \\
\hline $\begin{array}{l}\text { Sequential cholesterol-genetic } \\
\text { screening plus RCT }\end{array}$ & $1,636.4$ & 921,203 & 5,489 & 986 & 5,489 \\
\hline $\begin{array}{l}\text { Sequential genetic-cholesterol } \\
\text { screening }\end{array}$ & $1,577.0$ & $2,986,548$ & 101,097 & SD & SD \\
\hline $\begin{array}{l}\text { Sequential genetic-cholesterol } \\
\text { screening plus RCT }\end{array}$ & $1,616.7$ & $3,025,657$ & 39,696 & SD & SD \\
\hline $\begin{array}{l}\text { Parallel cholesterol-genetic } \\
\text { screening }\end{array}$ & $1,607.6$ & $3,074,443$ & 47,075 & SD & SD \\
\hline $\begin{array}{l}\text { Parallel cholesterol-genetic } \\
\text { screening plus RCT }\end{array}$ & $1,647.2$ & $3,113,552$ & 27,879 & 201,494 & 201,494 \\
\hline
\end{tabular}


m. DSA adjustment: Discount rate $=5.0 \%$

ICER (£/QALY)

\begin{tabular}{lccccc}
\cline { 4 - 6 } & QALYs & Costs $(\mathfrak{E})$ & $\begin{array}{c}\text { versus no } \\
\text { screening }\end{array}$ & $\begin{array}{c}\text { versus next } \\
\text { lowest cost }\end{array}$ & $\begin{array}{c}\text { versus relevant } \\
\text { alternative }\end{array}$ \\
\hline No screening & 765.6 & 145,745 & - & - & - \\
\hline Cholesterol-only screening & 774.2 & 469,146 & 37,804 & 37,804 & ED \\
\hline $\begin{array}{l}\text { Sequential cholesterol-genetic } \\
\text { screening }\end{array}$ & 774.9 & 547,300 & 43,028 & 100,495 & ED \\
\hline $\begin{array}{l}\text { Sequential cholesterol-genetic } \\
\text { screening plus RCT }\end{array}$ & 786.4 & 578,782 & 20,849 & 2,752 & 20,849 \\
\hline $\begin{array}{l}\text { Sequential genetic-cholesterol } \\
\text { screening }\end{array}$ & 770.0 & $2,659,677$ & 574,675 & SD & SD \\
\hline $\begin{array}{l}\text { Sequential genetic-cholesterol } \\
\text { screening plus RCT }\end{array}$ & 784.6 & $2,699,946$ & 134,393 & SD & SD \\
\hline $\begin{array}{l}\text { Parallel cholesterol-genetic } \\
\text { screening }\end{array}$ & 775.3 & $2,729,824$ & 265,820 & SD & SD \\
\hline $\begin{array}{l}\text { Parallel cholesterol-genetic } \\
\text { screening plus RCT }\end{array}$ & 789.9 & $2,770,093$ & 107,767 & 611,804 & 611,804 \\
& & & & &
\end{tabular}

n. DSA adjustment: CVD risks $90 \%$ of base case estimates

\begin{tabular}{|c|c|c|c|c|c|}
\hline & \multirow[b]{2}{*}{ QALYs } & \multirow[b]{2}{*}{ Costs (£) } & \multicolumn{2}{|c|}{ ICER (£/QALY) } & \multirow[b]{2}{*}{$\begin{array}{l}\text { versus relevant } \\
\text { alternative }\end{array}$} \\
\hline & & & $\begin{array}{l}\text { versus no } \\
\text { screening }\end{array}$ & $\begin{array}{l}\text { versus next } \\
\text { lowest cost }\end{array}$ & \\
\hline No screening & $1,002.0$ & 210,053 & - & - & - \\
\hline Cholesterol-only screening & $1,018.2$ & 547,356 & 20,845 & 20,845 & ED \\
\hline $\begin{array}{l}\text { Sequential cholesterol-genetic } \\
\text { screening }\end{array}$ & $1,019.7$ & 626,774 & 23,607 & 53,989 & ED \\
\hline $\begin{array}{l}\text { Sequential cholesterol-genetic } \\
\text { screening plus RCT }\end{array}$ & $1,035.2$ & 661,346 & 13,609 & 2,229 & 13,609 \\
\hline $\begin{array}{l}\text { Sequential genetic-cholesterol } \\
\text { screening }\end{array}$ & $1,010.3$ & $2,731,094$ & 304,677 & SD & SD \\
\hline $\begin{array}{l}\text { Sequential genetic-cholesterol } \\
\text { screening plus RCT }\end{array}$ & $1,030.1$ & $2,775,317$ & 91,252 & SD & SD \\
\hline $\begin{array}{l}\text { Parallel cholesterol-genetic } \\
\text { screening }\end{array}$ & $1,020.4$ & $2,809,929$ & 141,392 & SD & SD \\
\hline $\begin{array}{l}\text { Parallel cholesterol-genetic } \\
\text { screening plus } \mathrm{RCT}\end{array}$ & $1,040.2$ & $2,854,152$ & 69,172 & 432,969 & 432,969 \\
\hline
\end{tabular}


o. DSA adjustment: CVD risks $80 \%$ of base case estimates

ICER (£/QALY)

\begin{tabular}{|c|c|c|c|c|c|}
\hline & \multirow[b]{2}{*}{ QALYs } & \multirow[b]{2}{*}{ Costs $(£)$} & \\
\hline & & & $\begin{array}{l}\text { versus no } \\
\text { screening }\end{array}$ & $\begin{array}{l}\text { versus next } \\
\text { lowest cost }\end{array}$ & $\begin{array}{l}\text { versus relevant } \\
\text { alternative }\end{array}$ \\
\hline No screening & $1,011.3$ & 195,509 & - & - & - \\
\hline Cholesterol-only screening & $1,026.3$ & 535,227 & 22,724 & 22,724 & ED \\
\hline $\begin{array}{l}\text { Sequential cholesterol-genetic } \\
\text { screening }\end{array}$ & $1,027.6$ & 614,865 & 25,713 & 58,597 & ED \\
\hline $\begin{array}{l}\text { Sequential cholesterol-genetic } \\
\text { screening plus RCT }\end{array}$ & $1,041.9$ & 651,892 & 14,941 & 2,601 & 14,941 \\
\hline $\begin{array}{l}\text { Sequential genetic-cholesterol } \\
\text { screening }\end{array}$ & $1,019.0$ & $2,717,785$ & 329,930 & SD & SD \\
\hline $\begin{array}{l}\text { Sequential genetic-cholesterol } \\
\text { screening plus RCT }\end{array}$ & $1,037.2$ & $2,765,147$ & 99,381 & SD & SD \\
\hline $\begin{array}{l}\text { Parallel cholesterol-genetic } \\
\text { screening }\end{array}$ & $1,028.3$ & $2,798,130$ & 153,198 & SD & SD \\
\hline $\begin{array}{l}\text { Parallel cholesterol-genetic } \\
\text { screening plus RCT }\end{array}$ & $1,046.5$ & $2,845,493$ & 75,283 & 471,355 & 471,355 \\
\hline
\end{tabular}

p. DSA adjustment: Undiagnosed cases treated at background rate

\begin{tabular}{|c|c|c|c|c|c|}
\hline & \multirow[b]{2}{*}{ QALYs } & \multirow[b]{2}{*}{ Costs (£) } & \multicolumn{3}{|c|}{ ICER (£/QALY) } \\
\hline & & & $\begin{array}{l}\text { versus no } \\
\text { screening }\end{array}$ & $\begin{array}{l}\text { versus next } \\
\text { lowest cost }\end{array}$ & $\begin{array}{l}\text { versus relevan } \\
\text { alternative }\end{array}$ \\
\hline No screening & $1,009.1$ & 265,734 & - & - & - \\
\hline Cholesterol-only screening & $1,022.4$ & 587,115 & 24,174 & 24,174 & ED \\
\hline $\begin{array}{l}\text { Sequential cholesterol-genetic } \\
\text { screening }\end{array}$ & $1,023.6$ & 665,086 & 27,536 & 64,514 & ED \\
\hline $\begin{array}{l}\text { Sequential cholesterol-genetic } \\
\text { screening plus RCT }\end{array}$ & $1,035.4$ & 685,867 & 15,966 & 1,760 & 15,966 \\
\hline $\begin{array}{l}\text { Sequential genetic-cholesterol } \\
\text { screening }\end{array}$ & $1,015.9$ & $2,778,633$ & 369,636 & SD & SD \\
\hline $\begin{array}{l}\text { Sequential genetic-cholesterol } \\
\text { screening plus RCT }\end{array}$ & $1,031.0$ & $2,805,215$ & 115,928 & SD & SD \\
\hline $\begin{array}{l}\text { Parallel cholesterol-genetic } \\
\text { screening }\end{array}$ & $1,024.2$ & $2,847,517$ & 170,896 & SD & SD \\
\hline $\begin{array}{l}\text { Parallel cholesterol-genetic } \\
\text { screening plus RCT }\end{array}$ & $1,039.3$ & $2,874,099$ & 86,327 & 560,918 & 560,918 \\
\hline
\end{tabular}


q. DSA adjustment: Cholesterol test true positive rate for sequential cholesterolgenetic US strategy $=62.5 \%$

${ }^{*}$ NB. Cholesterol-only cholesterol threshold not adjusted in DSA as not clear that performance would be acceptable even using thresholds of highest described posttest probability $(=0.53)$ in recent analysis, and not of concern as strategy dominated even at base case performance for this strategy

\begin{tabular}{|c|c|c|c|c|c|}
\hline & \multirow[b]{2}{*}{ QALYs } & \multirow[b]{2}{*}{ Costs $(£)$} & \multicolumn{3}{|c|}{ ICER (£/QALY) } \\
\hline & & & $\begin{array}{l}\text { versus no } \\
\text { screening }\end{array}$ & $\begin{array}{l}\text { versus next } \\
\text { lowest cost }\end{array}$ & $\begin{array}{l}\text { versus relevant } \\
\text { alternative }\end{array}$ \\
\hline No screening & 992.1 & 225,805 & - & - & - \\
\hline Cholesterol-only screening* & $1,009.5$ & 560,648 & 19,218 & 19,218 & ED \\
\hline $\begin{array}{l}\text { Sequential cholesterol-genetic } \\
\text { screening }\end{array}$ & $1,004.5$ & 610,384 & 31,078 & SD & SD \\
\hline $\begin{array}{l}\text { Sequential cholesterol-genetic } \\
\text { screening plus RCT }\end{array}$ & $1,015.5$ & 631,138 & 17,350 & 11,870 & 17,350 \\
\hline $\begin{array}{l}\text { Sequential genetic-cholesterol } \\
\text { screening }\end{array}$ & $1,001.0$ & $2,745,588$ & 282,813 & SD & SD \\
\hline $\begin{array}{l}\text { Sequential genetic-cholesterol } \\
\text { screening plus RCT }\end{array}$ & $1,022.6$ & $2,786,366$ & 83,960 & 302,049 & SD \\
\hline $\begin{array}{l}\text { Parallel cholesterol-genetic } \\
\text { screening }\end{array}$ & $1,011.9$ & $2,822,886$ & 131,170 & SD & SD \\
\hline $\begin{array}{l}\text { Parallel cholesterol-genetic } \\
\text { screening plus RCT }\end{array}$ & $1,033.5$ & $2,863,664$ & 63,736 & 7,098 & 123,857 \\
\hline
\end{tabular}

r. DSA adjustment: Universal screening appointment duration $=40$ minutes

\begin{tabular}{|c|c|c|c|c|c|}
\hline & \multirow[b]{2}{*}{ QALYS } & \multirow[b]{2}{*}{ Costs $(£)$} & \multicolumn{3}{|c|}{ ICER (£/QALY) } \\
\hline & & & $\begin{array}{l}\text { versus no } \\
\text { screening }\end{array}$ & $\begin{array}{l}\text { versus next } \\
\text { lowest cost }\end{array}$ & $\begin{array}{l}\text { versus relevant } \\
\text { alternative }\end{array}$ \\
\hline No screening & 991.9 & 226,236 & - & - & - \\
\hline Cholesterol-only screening & 1009.3 & 613,460 & 22,244 & 22,244 & ED \\
\hline $\begin{array}{l}\text { Sequential cholesterol-genetic } \\
\text { screening }\end{array}$ & 1010.9 & 692,658 & 24,561 & 50,045 & ED \\
\hline $\begin{array}{l}\text { Sequential cholesterol-genetic } \\
\text { screening plus RCT }\end{array}$ & 1027.7 & 724,573 & 13,902 & 1,894 & 13,902 \\
\hline $\begin{array}{l}\text { Sequential genetic-cholesterol } \\
\text { screening }\end{array}$ & 1000.8 & $2,798,384$ & 288,946 & SD & SD \\
\hline $\begin{array}{l}\text { Sequential genetic-cholesterol } \\
\text { screening plus RCT }\end{array}$ & 1022.3 & $2,839,209$ & 85,779 & SD & SD \\
\hline $\begin{array}{l}\text { Parallel cholesterol-genetic } \\
\text { screening }\end{array}$ & 1011.6 & $2,875,703$ & 133,934 & SD & SD \\
\hline $\begin{array}{l}\text { Parallel cholesterol-genetic } \\
\text { screening plus RCT }\end{array}$ & 1033.2 & $2,916,527$ & 65,074 & 398,808 & 398,808 \\
\hline
\end{tabular}


Supplementary File 8: Cost-effectiveness acceptability curves

Probability of cost-effectiveness of sequential cholesterol-genetic plus reverse cascade testing (RCT) versus no screening is displayed for the base case (black line) and deterministic sensitivity analysis scenarios that modelled a definition of familial hypercholesterolaemia that included all mutation-positive individuals $(A)$, different RCT yields (B), off-patent drug costs (C), lower cardiovascular (CVD) risk estimates (D), alternative discount rates (E) and background lipid modifying treatment $(F) ;{ }^{*} A: 6.1$ relatives identified with probability $=0.4 ; 2.5$ with probability $=$ 0.2 ; B: 6.1 identified with probability $=0.4 ; 2.5$ with probability $=0.1$
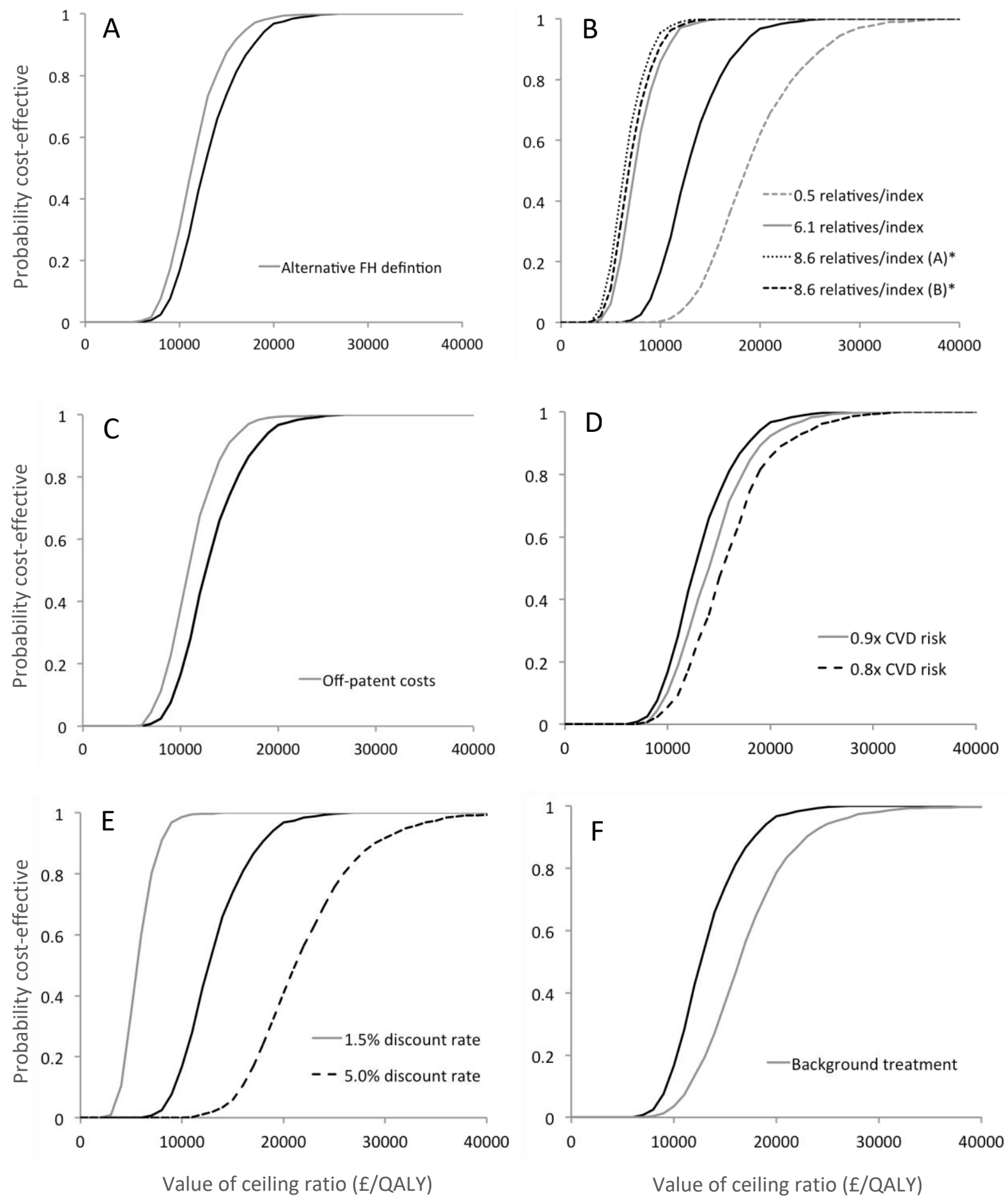


\section{Supplementary File 9: Additional references}

Curtis L, Burns A. Unit Costs of Health and Social Care 2016, Personal Social Services Research Unit, University of Kent, Canterbury, 2016. Available at: http://www.pssru.ac.uk/project-pages/unit-costs/unit-costs-2016/. Accessed: September 2017.

Haralambos K, Wales Heart Research Institute, Cardiff. [Personal communication]

HM Revenue \& Customs: Rates and allowances: HM Revenue and Customs, PAYE, and Tax agent and adviser guidance. HMRC, February 2017 (updated August 2017). Available at: https://www.gov.uk/guidance/rates-andthresholds-for-employers-2017-to-2018. Accessed: September 2017.

Medicines and Healthcare products Regulatory Agency. Simvastatin: increased risk of myopathy at high dose (80 mg). Drug Safety Update May 2010, vol 3 issue 10:7.

National Clinical Guideline Centre. NICE clinical guideline CG181: Lipid modification: Cardiovascular risk assessment and the modification of blood lipids for the primary and secondary prevention of cardiovascular disease. Clinical Guideline Appendices. NICE, July 2014 (updated September 2016). Available at: https://www.nice.org.uk/guidance/cg181/evidence. Accessed: September 2017.

National Institute for Health and Care Excellence. Cardiovascular disease: risk assessment and reduction, including lipid modification (CG181). NICE, 2014. Available at: https://www.nice.org.uk/guidance/cg181. Accessed: September 2017.

National Institute for Health and Care Excellence. CG68: Stroke and transient ischaemic attack in over 16s: diagnosis and initial management. NICE, July 2008 (updated March 2017). Available at: https://www.nice.org.uk/guidance/cg68. Accessed: September 2017.

National Institute for Health and Care Excellence. Familial hypercholesterolaemia costing template. NICE, December 2009.

National Institute for Health and Care Excellence. Familial hypercholesterolaemia: identification and management : guidance (CG71). NICE, 2008 (Last updated Novemeber 2017).

Neil HAW. Problems in measurement: cholesterol. In: Lawrence M, Neil A, Mant D, Fowerler GH, eds. Prevention of cardiovascular disease - an evidencebased approach. Oxford: Oxford University Press, 1996. pp.253-7.

NHS Business Services Authority. Drug Tariff (September 2017). Available at: https://www.nhsbsa.nhs.uk/pharmacies-gp-practices-and-appliancecontractors/drug-tariff. Accessed: September 2017.

NHS Business Services Authority. NHS Pensions - Costs and contributions for the scheme years 2015/2016 through to 2018/2019. NHSBSA, March 2017.

Available at: https://www.nhsbsa.nhs.uk/sites/default/files/201703/Cost $\% 20$ and $\% 20$ contributions $\% 20$ factsheet $\% 202015$ 16\%20\%280fficer\%29\%20\%2803.2017\%29\%20V3.pdf. Accessed: September 2017.

NHS England and NHS Improvement. 2017/18 and 2018/19 National Tariff Payment System. December 2016. Available at: 
https://improvement.nhs.uk/resources/national-tariff-1719/. Accessed: September 2017.

NHS Greater Huddersfield Clinical Commissioning Group. Information on the number and cost of diagnostic test services. Dataset A: 2014-15. Available at: https://www.greaterhuddersfieldccg.nhs.uk/wpcontent/uploads/FOI/2015-16/002FOI15.16 Diabetic Datasets.pdf. Accessed: September 2017.

The NHS Staff Council. NHS terms and conditions of service handbook. Amendment number 38 Pay and Conditions Circular (AforC) number 1/2017. Available at: http://www.nhsemployers.org/tchandbook. Accessed: September 2017.

Nordstrom BL, Collins JM, Donaldson R, Engelman WA, Tockhorn A, Zhu Y, Zhao Z. Treatment patterns and lipid levels among patients with high-risk atherosclerotic CVD in the UK. Br J Cardiol 2015;22:147-54.

Northern, Eastern and Western Devon Clinical Commissioning Group. Information on the Number and Cost of Diagnostic Test Services: Dataset B 2015-2016. Available at: http://www.northdevonhealth.nhs.uk/wpcontent/uploads/2014/03/FOI-15-012-NDHT2015Diabetes 1 DataSet B-21May15.pdf. Accessed: September 2017.

Office for National Statistics. Mortality statistics - underlying cause, sex and age [dataset]. Available at:

https://www.nomisweb.co.uk/query/select/getdatasetbytheme.asp?opt $=3 \&$ theme=\&subgrp $=$. Accessed: September 2017.

Office for National Statistics. Population estimates - local authority based by five year age band [dataset]. Available at:

https://www.nomisweb.co.uk/query/select/getdatasetbytheme.asp?the $\underline{\text { me}}=32$ Accessed: September 2017.

Pedersen KMV, Humphries SE, Roughton M, Besford JS. National Clinical Audit of the Management of Familial Hypercholesterolaemia 2010: Full Report. Clinical Standards Department, Royal College of Physicians, December 2010.

Screening \& Immunisations Team, NHS Digital. NHS Immunisation Statistics: England, 2015-16. NHS Digitial, September 2016. Available at: https://digital.nhs.uk/catalogue/PUB21651. Accessed: September 2017.

Ward S, Lloyd Jones M, Pandor A, et al. Statins for the Prevention of Coronary Events: Technology assessment report commissioned by the HTA Programme on behalf of the National Institute for Clinical Excellence. London. National Institute for Health and Clinical Excellence, 2005.

Scientific Steering Committee on behalf of the Simon Broome Register Group. 1991. Risk of fatal coronary heart disease in familial hypercholesterolaemia. BMJ, 303, 893-896.

Akioyamen, LE, Genest, J, Shan, SD, Reel, RL, Albaum, JM, Chu, A \& Tu, JV 2017. Estimating the prevalence of heterozygous familial hypercholesterolaemia: a systematic review and meta-analysis. BMJ Open, 7, e016461.

Bhatnagar P, Wickramasinghe K, Wilkins E \& Townsend N, 2016. Trends in the epidemiology of cardiovascular disease in the UK. Heart, 102, 1945-1952.

Carey IM, Dewilde S, Shah SM, Harris T, Whincup PH, Cook DG, 2012. Statin use after first myocardial infarction in UK men and women from 1997 to 
2006: Who started and who continued treatment? Nutrition, Metabolism and Cardiovascular Diseases, 22, 400-408.

Civeira, F, Ros, E, Jarauta, E, et al 2008. Comparison of genetic versus clinical diagnosis in familial hypercholesterolemia. Am J Cardiol, 102, 1187-93, 1193.e1.

Damgaard D, Larsen ML, Nissen PH, et al, 2005. The relationship of molecular genetic to clinical diagnosis of familial hypercholesterolemia in a Danish population. Atherosclerosis, 180, 155-160.

Fleetcroft R, Schofield P, Ashworth M, 2014. Variations in statin prescribing for primary cardiovascular disease prevention: cross-sectional analysis. BMC Health Services Research, 14, 414.

Ford I, Murray H, Mccowan C, Packard CJ, 2016. Long-Term Safety and Efficacy of Lowering Low-Density Lipoprotein Cholesterol With Statin Therapy: 20Year Follow-Up of West of Scotland Coronary Prevention Study. Circulation, 133, 1073-1080.

Futema M, Cooper JA, Charakida M, et al, 2017. Screening for familial hypercholesterolaemia in childhood: Avon Longitudinal Study of Parents and Children (ALSPAC). Atherosclerosis, 260, 47-55.

Futema M, Whittall RA, Kiley A, et al, 2013. Analysis of the frequency and spectrum of mutations recognised to cause familial hypercholesterolaemia in routine clinical practice in a UK specialist hospital lipid clinic. Atherosclerosis, 229, 161-168.

Galema-Boers JMH, Lenzen MJ, Van Domburg RT, et al, 2014. Predicting nonadherence in patients with familial hypercholesterolemia. European Journal of Clinical Pharmacology, 70, 391-397.

Graham CA, Mcilhatton BP, Kirk CW, et al, 2005. Genetic screening protocol for familial hypercholesterolemia which includes splicing defects gives an improved mutation detection rate. Atherosclerosis, 182, 331-340.

Hadfield SG, Horara S, Starr,BJ, et al, 2009. Family tracing to identify patients with Familial Hypercholesterolaemia: the second Audit of the Department of Health Familial Hypercholesterolaemia Cascade Testing Project. Annals of Clinical Biochemistry, 46, 24-32.

Hippisley-Cox J, Coupland C, Vinogradova Y, et al, 2008. Predicting cardiovascular risk in England and Wales: prospective derivation and validation of QRISK2. BMJ, 336, 1475.

Juul-Moller S, Edvardsson N, Sorensen S, Jahnmatz B, Rosén A, Omblus R, 1992. Double-blind trial of aspirin in primary prevention of myocardial infarction in patients with stable chronic angina pectoris. The Lancet, 340, 1421-1425.

Kerr M, Pears R, Miedzybrodzka Z, et al, 2017. Cost effectiveness of cascade testing for familial hypercholesterolaemia, based on data from familial hypercholesterolaemia services in the UK. European Heart Journal, 38, 1832-1839.

Khera AV, Won HH, Peloso GM, et al, 2016. Diagnostic Yield of Sequencing Familial Hypercholesterolemia Genes in Severe Hypercholesterolemia. Journal of the American College of Cardiology, 67, 2578-2589.

Klančar G, Grošelj U, Kovač J, et al, 2015. Universal Screening for Familial Hypercholesterolemia in Children. Journal of the American College of Cardiology, 66, 1250-1257. 
Kusters DM, Avis HJ, De Groot E, et al, 2014. Ten-year follow-up after initiation of statin therapy in children with familial hypercholesterolemia. JAMA, 312, 1055-7.

Marks, D 2006. Cascade screening for familial hypercholesterolaemia: implications of a pilot study for national screening programmes. Journal of Medical Screening, 13, 156-159.

Morris JK, Wald DS, Wald NJ, 2012. The evaluation of cascade testing for familial hypercholesterolemia. Am J Med Genet A, 158a, 78-84.

Nanchen D, Gencer B, Auer R, et al, 2015. Prevalence and management of familial hypercholesterolaemia in patients with acute coronary syndromes. Eur Heart J, 36, 2438-45.

Nordestgaard BG, Chapman MJ, Humphries SE, et al, 2013. Familial hypercholesterolaemia is underdiagnosed and undertreated in the general population: guidance for clinicians to prevent coronary heart disease: consensus statement of the European Atherosclerosis Society. Eur Heart J, 34, 3478-90a.

O'Keeffe AG, Nazareth I, Petersen I, 2016. Time trends in the prescription of statins for the primary prevention of cardiovascular disease in the United Kingdom: a cohort study using The Health Improvement Network primary care data. Clinical Epidemiology, 8, 123-132.

Ramaswami U, Cooper J, Humphries SE, 2017. The UK Paediatric Familial Hypercholesterolaemia Register: Preliminary data. Archives of Disease in Childhood, 102, 255-260.

Starr B, Hadfield SG, Hutten BA, et al, 2008. Development of sensitive and specific age- and gender-specific low-density lipoprotein cholesterol cutoffs for diagnosis of first-degree relatives with familial hypercholesterolaemia in cascade testing. Clinical Chemistry and Laboratory Medicine, 46, 791-803.

Umans-Eckenhausen MA, Defesche JC, Sijbrands EJ, Scheerder RL, Kastelein JJ, 2001. Review of first five years of screening for familial hypercholesterolaemia in the Netherlands. Lancet, 357, 165-168.

Wald DS, Bestwick JP, Morris JK, Whyte K, Jenkins L, Wald NJ, 2016. Child-Parent Familial Hypercholesterolemia Screening in Primary Care. New England Journal of Medicine, 375, 1628-1637.

Wald DS, Bestwick JP, Wald NJ, 2007. Child-parent screening for familial hypercholesterolaemia: Screening strategy based on a meta-analysis. British Medical Journal, 335, 599-603.

Watts GF, Gidding S, Wierzbicki AS, et al, 2015. Integrated guidance on the care of familial hypercholesterolaemia from the International FH Foundation. European Journal of Preventive Cardiology, 22, 849-854. 